OPEN ACCESS

Edited by:

Colleen Hansel,

Woods Hole Oceanographic Institution, USA

Reviewed by:

William P. Inskeep,

Montana State University, USA

William Sunda,

National Oceanic and Atmospheric

Administration, USA

*Correspondence:

T. David Waite

d.waite@unsw.edu.au

Specialty section:

This article was submitted to

Marine Biogeochemistry,

a section of the journal

Frontiers in Marine Science

Received: 15 March 2016

Accepted: 19 July 2016

Published: 04 August 2016

Citation:

Miller CJ, Rose AL and Waite TD

(2016) Importance of Iron

Complexation for Fenton-Mediated

Hydroxyl Radical Production at

Circumneutral $\mathrm{pH}$.

Front. Mar. Sci. 3:134.

doi: 10.3389/fmars.2016.00134

\section{Importance of Iron Complexation for Fenton-Mediated Hydroxyl Radical Production at Circumneutral pH}

\author{
Christopher J. Miller ${ }^{1}$, Andrew L. Rose ${ }^{1,2}$ and T. David Waite ${ }^{1 *}$ \\ ${ }^{1}$ School of Civil and Environmental Engineering, UNSW Australia, Sydney, NSW, Australia, ${ }^{2}$ Southern Cross GeoScience, \\ Southern Cross University, Lismore, NSW, Australia
}

The reaction between $\mathrm{Fe}(\mathrm{II})$ and $\mathrm{H}_{2} \mathrm{O}_{2}$ to yield hydroxyl radicals $(\mathrm{HO} \bullet)$, the Fenton reaction, is of interest due to its role in trace metal and natural organic matter biogeochemistry, its utility in water treatment and its role in oxidative cell degradation and associated human disease. There is significant dispute over whether $\mathrm{HO}^{\bullet}$, the most reactive of the so-called reactive oxygen species (ROS), is formed in this reaction, particularly under circumneutral conditions relevant to natural systems. In this work we have studied the oxidation kinetics of $F e(I I)$ complexed by $L=$ citrate, ethylenediaminetetraacetic acid (EDTA) and diethylenetriaminepentaacetic acid (DTPA) and also measured $\mathrm{HO}^{\bullet}$ production using phthalhydrazide as a probe compound at $\mathrm{pH}$ 8.2. A kinetic model has been developed and utilized to confirm that $\mathrm{HO}$ is the sole product of the $\mathrm{Fe}(\mathrm{II}) \mathrm{L}-\mathrm{H}_{2} \mathrm{O}_{2}$ reaction for $\mathrm{L}=\mathrm{EDTA}$ and DTPA. Quantitative $\mathrm{HO}^{\bullet}$ production also appears likely for $\mathrm{L}=$ citrate, although uncertainties with the speciation of $\mathrm{Fe}(\mathrm{II})$-citrate complexes as well as difficulties in modeling the oxidation kinetics of these complexes has prevented a definitive conclusion. In the absence of ligands at circumneutral $\mathrm{pH}$, inorganic $\mathrm{Fe}(\mathrm{II})$ reacts with $\mathrm{H}_{2} \mathrm{O}_{2}$ to yield a species other than $\mathrm{HO}$, contrary to the well-established production of $\mathrm{HO}^{\bullet}$ from inorganic $\mathrm{Fe}(\mathrm{II})$ at low $\mathrm{pH}$. Our results suggest that at high $\mathrm{pH} \mathrm{Fe}(\mathrm{II})$ must be complexed for $\mathrm{HO} \bullet$ production to occur.

Keywords: reactive oxygen species, hydroxyl radical, Fenton, EDTA, DTPA, citrate

\section{INTRODUCTION}

The reaction between $\mathrm{Fe}(\mathrm{II})$ and $\mathrm{H}_{2} \mathrm{O}_{2}$ (the Fenton reaction) occurs naturally in aquatic environments (White et al., 2003), biological systems (Backa et al., 1993; Winterbourn, 1995; Jomova et al., 2012; Lee et al., 2012), and is also employed in water treatment applications (von Sonntag, 2008). Although ubiquitous and an important source of reactive oxygen species (ROS), if $\mathrm{HO}^{\bullet}$ is indeed produced, the identity of the intermediate formed in this reaction has long been the subject of debate (Goldstein et al., 1993; MacFaul et al., 1998; Walling, 1998; Goldstein and Meyerstein, 1999; Dunford, 2002; Rachmilovich-Calis et al., 2009a; Remucal Keenan and Sedlak, 2011). It is generally accepted that $\mathrm{HO}^{\bullet}$ is formed under acidic conditions and in the absence of ligands. However, an alternative mechanism invoking higher valent Fe complexes such as $\mathrm{Fe}(\mathrm{IV})$, first proposed by Bray and Gorin (1932), is also consistent with many findings (Kremer, 1999). Under circumneutral conditions the mechanism is particularly controversial (Remucal Keenan and Sedlak, 2011), with recent studies now mostly in agreement that at higher $\mathrm{pH}$ the product of the Fenton reaction with inorganic $\mathrm{Fe}(\mathrm{II})$ shifts to a species other than $\mathrm{HO}^{\bullet}$, possibly to a high-valent 
Fe species such as Fe(IV) (Hug and Leupin, 2003; Keenan and Sedlak, 2008; Bataineh et al., 2012; Lee et al., 2013). The underlying cause of this is not clear. The presence of organic ligands that are important to the speciation of $\mathrm{Fe}(\mathrm{II})$ in natural waters (Roy and Wells, 2011; Hopwood et al., 2015), as well as those employed to solubilize Fe under circumneutral conditions in industrial practices, complicates this further.

For reasons which will be discussed later, we have examined the ligands citrate, ethylenediaminetetraacetic acid (EDTA), and diethylenetriaminepentaacetic acid (DTPA) in this study. Despite extensive study, it is still not clear whether or not $\mathrm{HO}^{\bullet}$ is formed when the $\mathrm{Fe}$ (II) complexes of these ligands are oxidized by $\mathrm{H}_{2} \mathrm{O}_{2}$. Previous investigations have used a wide array of probe compounds to examine the nature of the oxidative intermediate formed in this reaction. By consideration of these methodologies used in this earlier work, particularly their limitations, it has been possible to design a study to avoid these issues and more-effectively isolate the $\mathrm{Fe}(\mathrm{II}) \mathrm{L}-\mathrm{H}_{2} \mathrm{O}_{2}$ reaction. For example, Rahhal and Richter $(1988,1989)$ compared the impact of $t$-BuOH and $\mathrm{MeOH}$ upon the reaction stoichiometry and kinetics when $\mathrm{Fe}(\mathrm{II}) / \mathrm{Fe}$ (III)DTPA solutions reacted with $\mathrm{H}_{2} \mathrm{O}_{2}$ or were exposed to radiolytically produced $\mathrm{HO}^{\bullet}$ and concluded that $\mathrm{HO}^{\bullet}$ could not be the reactive intermediate. Similar work however by Rush and Koppenol (1987) (with L = EDTA and DTPA) employing a wider range of scavengers was generally consistent with $\mathrm{HO}^{\bullet}$ formation (although $t$ - $\mathrm{BuOH}$ and benzoate scavengers yielded contradictory results), in direct contrast to their own earlier work which suggested that $\mathrm{HO}^{\bullet}$ was not formed by peroxidation of Fe(II)EDTA (Rush and Koppenol, 1986). Luzzatto et al. (1995) later examined the $\mathrm{Fe}(\mathrm{II}) \mathrm{EDTA}-\mathrm{H}_{2} \mathrm{O}_{2}$ system using a $\beta$-elimination based assay with alcohol probe compounds, concluding that $\mathrm{Fe}(\mathrm{II})$ EDTA reacts with $\mathrm{H}_{2} \mathrm{O}_{2}$ to yield $\mathrm{HO}^{\bullet}$. All these studies were undertaken in deoxygenated solutions at relatively high $\mathrm{Fe}$ concentrations $\left(10^{-5}-10^{-3} \mathrm{M}\right)$, under which conditions the relatively poorly studied reactions between organic radical intermediates (whatever their mode of formation) and $\mathrm{FeL}$ species potentially become important. Although - $\mathrm{CH}_{2} \mathrm{COH}\left(\mathrm{CH}_{3}\right) \mathrm{CH}_{3}$ radicals formed from the reaction of $\mathrm{HO}^{\bullet}$ and $t$-BuOH were shown to be unreactive toward Fe-DTPA complexes (Rahhal and Richter, 1989) and unable to reduce Fe(III)EDTA (Rush and Koppenol, 1987), Croft et al. (1992) suggested that they could oxidize Fe(II)EDTA. Fe(III)EDTA has also been shown to oxidize $\mathrm{CO}_{2}^{\bullet-}$ radicals (Rush and Koppenol, 1987). Most carbon-centered organic radicals also typically react rapidly with $\mathrm{O}_{2}$. It is possible that incomplete $\mathrm{O}_{2}$-exclusion further complicated the analysis of the earlier work, as even very small amounts of $\mathrm{O}_{2}$ will lead to competition between $\mathrm{O}_{2}$ and Fe species for the organic radicals (Rush and Koppenol, 1987). It would therefore seem likely that the complications introduced from the poorly-studied reactions between Fe and the carboncentered radicals may be the reason for the discrepancies in these previous studies.

The nature of the intermediate formed has also been proposed to be dependent upon the initial reactant concentrations. Yamazaki and Piette $(1990,1991)$ studied the $\mathrm{Fe}(\mathrm{II}) \mathrm{L}-\mathrm{H}_{2} \mathrm{O}_{2}$ $(\mathrm{L}=\mathrm{EDTA}$, DTPA) reaction under oxic conditions by DMPO spin trapping concluding that $\mathrm{Fe}(\mathrm{II}) \mathrm{DTPA}$ produces only $\mathrm{HO}^{\bullet}$.
They demonstrated that $\mathrm{HO}^{\bullet}$ formation was quantitative at low $\mathrm{Fe}(\mathrm{II})$ concentrations $\left(<10^{-6} \mathrm{M}\right)$. However, competitive scavenging with $t$ - $\mathrm{BuOH}$ was not consistent with $\mathrm{HO}^{\bullet}$ formation, in agreement with similar observations by Rahhal and Richter (1988). Based upon observation of an increase in the total trapped spin when ethanol (EtOH) was added to the system, they also suggested that $\mathrm{Fe}$ (II)EDTA peroxidation forms another oxidative intermediate in addition to $\mathrm{HO}^{\bullet}$. This concentration dependence however could also conceivably be caused by competition between DMPO and Fe-L complexes for the oxidant.

Croft et al. (1992) undertook a detailed ESR study of the $\mathrm{Fe}(\mathrm{II}) \mathrm{EDTA} / \mathrm{H}_{2} \mathrm{O}_{2}$ system by monitoring organic radicals formed from substrate oxidation. With carefully controlled studies they demonstrated that anomalous results from scavenging experiments could be explained if oxidation/reduction of organic radicals by $\mathrm{Fe}(\mathrm{III}) \mathrm{L} / \mathrm{Fe}(\mathrm{II}) \mathrm{L}$ and $\mathrm{H}_{2} \mathrm{O}_{2}$ was incorporated into the modeling. Previous anomalous results in the $\mathrm{Fe}(\mathrm{II}) \mathrm{EDTA} / \mathrm{H}_{2} \mathrm{O}_{2}$ system with $t$ - $\mathrm{BuOH}$ and $\mathrm{EtOH}$ as scavengers were thus reconciled when reduction of $t-\mathrm{BuOH}$ and $\beta$-EtOH radicals by $\mathrm{Fe}(\mathrm{II}) \mathrm{EDTA}$ and oxidation of $\alpha$-EtOH radicals by $\mathrm{Fe}$ (III)EDTA was invoked. Often contradictory results have been rationalized by insufficient consideration of intermediate organic radical species, which may further oxidize $\mathrm{Fe}(\mathrm{II})$ or reduce $\mathrm{Fe}(\mathrm{III})$, depending upon the nature of the radical thus formed (Croft et al., 1992; Kosaka et al., 1992; Yurkova et al., 1999).

In comparison to the Fe(II)-EDTA/DTPA system, the Fe(II)citrate system has been studied comparatively little. Gutteridge (1991) provided evidence that citrate is able to reduce $\mathrm{Fe}(\mathrm{III})$, with the $\mathrm{Fe}(\mathrm{II})$-citrate thus formed able to produce $\mathrm{HO}^{\bullet}$, although the mechanism was not examined nor was quantitative production confirmed (note that the reduction process is not significant at the concentrations and time scales used in this work). Studies on the photo-reduction of $\mathrm{Fe}$ (III)-citrate in the presence of $\mathrm{H}_{2} \mathrm{O}_{2}$ also support the formation of $\mathrm{HO}^{\bullet}$, although details of reaction rates were not examined (Zepp et al., 1992). Vile et al. (1987) directly studied the reaction between $\mathrm{H}_{2} \mathrm{O}_{2}$ and $\mathrm{Fe}(\mathrm{II})$-citrate (Fe(II)cit) and suggested that an oxidant whose properties are consistent with $\mathrm{HO}^{\bullet}$ is formed based upon formation of similar thiobarbituric acid reactive substances (TBARS) to those formed during deoxyribose degradation with $\mathrm{Fe}$ (II)EDTA, which was considered to produce $\mathrm{HO}^{\bullet}$ based upon the impact of various scavengers. Separate experiments measuring $\mathrm{CO}_{2}$ formation during formate oxidation demonstrated that $\mathrm{Fe}(\mathrm{II})$ cit peroxidation produces $60 \%$ less $\mathrm{HO}^{\bullet}$ than $\mathrm{Fe}(\mathrm{II})$ EDTA peroxidation. The extent of deoxyribose degradation by $\mathrm{Fe}(\mathrm{II}) \mathrm{cit}$ was similar to that observed with $\mathrm{Fe}(\mathrm{II}) \mathrm{EDTA}$, whereas inorganic $\mathrm{Fe}(\mathrm{II})$ produced $\sim 3$ to 4 -fold more TBARS, suggesting that inorganic Fe(II) may produce $\mathrm{HO}^{\bullet}$. Results from this work should be considered with some caution in light of more recent evidence regarding the inherent complexity of interpreting results from the TBARS method (Rachmilovich-Calis et al., 2009b).

From these previous studies it is clear that there is significant disagreement as to the reactive intermediate formed in these systems and that detailed consideration of the fate of any organic radicals formed must be considered in any quantitative analysis, 
as highlighted by Masarwa et al. (2005). By consideration of the fate of these radical species it is conceivable that a kinetic model may be constructed that could adequately describe the concentration profiles of $\mathrm{Fe}(\mathrm{II}) / \mathrm{Fe}(\mathrm{III})$, as well as any production of $\mathrm{HO}^{\bullet}$, should it indeed be formed. The main drawback with such an approach is the paucity of studies into the reactivity of carbon-centered radicals with $\mathrm{Fe}$, especially when complexed by organic ligands. However, most carbon-centered radicals react at near diffusion-controlled rates with $\mathrm{O}_{2}$ to yield organoperoxyl radicals, with some of these organoperoxyl radicals subsequently rapidly eliminating $\mathrm{O}_{2}^{\bullet-}$ (von Sonntag et al., 1997), with the reactions of $\mathrm{O}_{2}^{\bullet-}$ and $\mathrm{Fe}$-complexes thoroughly investigated. Therefore, provided $\mathrm{Fe}$ concentrations are significantly lower than $\mathrm{O}_{2}$ concentrations, and the organoperoxyl radicals that are formed are of the type that rapidly eliminate $\mathrm{O}_{2}^{\bullet-}$, any potential reaction between $\mathrm{Fe}$ and these carbon-centered radicals will be insignificant. Under such conditions organic radicals are effectively converted to $\mathrm{O}_{2}^{\bullet-}$, a species with well-known reactivity with $\mathrm{Fe}$ and $\mathrm{Fe}$-complexes. This study has been designed around these requirements to allow for a definitive conclusion to be reached, and to avoid the complications that have plagued earlier work in this area.

In the present study the oxidation of inorganic $\mathrm{Fe}(\mathrm{II})$ and $\mathrm{Fe}(\mathrm{II}) \mathrm{L}$ by $\mathrm{H}_{2} \mathrm{O}_{2}$ was examined under oxic conditions at low micromolar concentrations of $\mathrm{Fe}(\mathrm{II})$, combining measurements of $\mathrm{Fe}(\mathrm{II})$ oxidation kinetics, $\mathrm{HO}^{\bullet}$ production kinetics, and competition between well-defined competitive $\mathrm{HO}^{\bullet}$ scavengers and the $\mathrm{HO}^{\bullet}$ trapping agent phthalhydrazide (Phth). Kinetic modeling was then used to quantitatively examine whether $\mathrm{HO}^{\bullet}$ was the key intermediate formed. By employing oxic conditions with relatively low concentrations of $\mathrm{FeL}$ and $\mathrm{H}_{2} \mathrm{O}_{2}$, the fate of intermediate organic radicals was determined by well-defined $\mathrm{O}_{2}$-mediated pathways, resulting in minimal interference to the $\mathrm{Fe}(\mathrm{II}) \mathrm{L}-\mathrm{H}_{2} \mathrm{O}_{2}$ system under study. This approach, combined with quantitative kinetic modeling incorporating the fate and further interaction of intermediate organic radical species, has allowed the $\mathrm{Fe}(\mathrm{II}) \mathrm{L}-\mathrm{H}_{2} \mathrm{O}_{2}$ reaction to be effectively isolated and studied. A critical aspect of this approach is being able to reasonably predict the actual fate of any oxidizing radical formed, as well as the kinetics and mechanism of $\mathrm{Fe}$ (II) oxidation [and potentially $\mathrm{Fe}$ (III) reduction] in the presence of the ligand. For this reason, well-defined synthetic ligands $(\mathrm{L}=$ citrate, EDTA and DTPA) for which the relevant chemistry is reasonably well-understood have been employed in place of the poorly characterized ligands that are typical of marine, estuarine and freshwater systems. A low ionic strength has been used in this study to prevent introduction of redox-active contaminants from the salt solutions, as well as to simplify the kinetic and thermodynamic treatment of the Fe-ligand interaction which can be greatly complicated by high concentrations of cations such as $\mathrm{Mg}^{2+}$ and $\mathrm{Ca}^{2+}$ (Fujii et al., 2008; Miller et al., 2012).

\section{MATERIALS AND METHODS}

\section{Chemicals}

Solutions were prepared in $18 \mathrm{M} \Omega . \mathrm{cm}$ Milli-Q water (MQ) obtained from a Millipore Milli-Q system. Glassware and plasticware were soaked for 3 days in $0.5 \mathrm{M} \mathrm{HCl}$. Reagents were of analytical reagent grade unless noted otherwise. EDTA and DTPA were added from stock solutions adjusted to $\mathrm{pH}$ $\approx 7.2$ while citrate was added to solutions as solid disodium hydrogen citrate sesquihydrate $\left(\mathrm{C}_{6} \mathrm{H}_{6} \mathrm{Na}_{2} \mathrm{O}_{7} \cdot 1.5 \mathrm{H}_{2} \mathrm{O}\right) . \mathrm{H}_{2} \mathrm{O}_{2}$ stock solutions were prepared by dilution of a $30.7 \% \mathrm{w} / \mathrm{v} \mathrm{H}_{2} \mathrm{O}_{2}$ solution (Riedel-de Haën, stabilized with $40 \mathrm{mg} / \mathrm{L}$ dipicolinic acid) and standardized spectrophotometrically using $\varepsilon_{250}=$ $22.7 \mathrm{M}^{-1} \cdot \mathrm{cm}^{-1}$ (Morgan et al., 1988). Fe(II) stock solutions were prepared daily from $\mathrm{Fe}(\mathrm{II}) \mathrm{SO}_{4} \cdot 7 \mathrm{H}_{2} \mathrm{O}(4 \mathrm{mM})$ and adjusted to $\mathrm{pH} 4$ with $\mathrm{HCl} .1 \mathrm{M} \mathrm{Na} \mathrm{CO}_{3}$ buffer was prepared by dissolving $\mathrm{Na}_{2} \mathrm{CO}_{3}$ in $\mathrm{MQ}$ and allowing it to stand for several days. It was then filtered to remove precipitates $(0.22 \mu \mathrm{m}$ Millipore Millex-GV PVDF membrane) and then adjusted to pH 11 with $32 \% \mathrm{HCl} . \mathrm{K}_{5} \mathrm{Cu}\left(\mathrm{HIO}_{6}\right)_{2}(\mathrm{Cu}(\mathrm{III}))$ was synthesized as described previously (Miller et al., 2011). For scavenging experiments, appropriate amounts of sodium formate (SigmaAldrich, 99+\% ACS Reagent grade) or 2-methyl-propan-2ol $(t-\mathrm{BuOH}$, Ajax Analytical Reagent grade) were added to the standard reaction matrix, which consisted of $10 \mathrm{mM} \mathrm{NaCl}$ and $2 \mathrm{mM} \mathrm{NaHCO}$. When performing $\mathrm{HO}^{\bullet}$ production experiments, $0.55 \mathrm{mM}$ phthalhydrazide (Phth, 99\%, Aldrich) was also added to the standard matrix. In all experiments the $\mathrm{pH}$ of the matrix was adjusted to $8.20 \pm 0.05$ with $\mathrm{HCl}$ and/or $\mathrm{NaOH}$, which remained relatively constant $( \pm 0.05$ $\mathrm{pH}$ units) during an experiment. All reactions were studied under conditions minimizing exposure to room lighting through use of brown glass vessels and shielding with aluminum foil.

\section{$\mathrm{Fe}(\mathrm{II})$ Oxidation Experiments}

The kinetics of $\mathrm{Fe}(\mathrm{II})$ cit oxidation by $\mathrm{O}_{2}$ and $\mathrm{H}_{2} \mathrm{O}_{2}$ were examined by monitoring the loss of $\mathrm{Fe}(\mathrm{II})$ using luminol chemiluminescence (Rose and Waite, 2001; Miller et al., 2009) with $[\mathrm{Fe}(\mathrm{II})]_{0}=0.2,0.6,1.2$, and $2 \mu \mathrm{M}$, where the subscript 0 denotes initial concentration. $\mathrm{Fe}(\mathrm{II}) \mathrm{L}$ oxidation kinetics $\left(\mathrm{L}=\right.$ EDTA or DTPA; $\left.[\mathrm{Fe}(\mathrm{II})]_{0}=2 \mu \mathrm{M}\right)$ were investigated by following $\mathrm{Fe}$ (III)L formation spectrophotometrically at $260 \mathrm{~nm}$ $\left[\varepsilon \approx 7600 \mathrm{M}^{-1} \cdot \mathrm{cm}^{-1}\right.$ for both complexes, background corrected at $500 \mathrm{~nm}$, with the molar absorbance coefficient determined here consistent with the values determined by Hill-Cottingham (1955) after accounting for the $\mathrm{pH}$ dependence]. In all cases, inorganic $\mathrm{Fe}(\mathrm{II})$ was added to a matrix containing an oxidant and ligand. Although explicitly considered during kinetic modeling, initial competition between Fe(II)-complex formation and oxidation of inorganic Fe(II) was expected to be minimal. This was confirmed by calculations using known rate constants for complex formation and inorganic $\mathrm{Fe}(\mathrm{II})$ oxidation for $\mathrm{L}=$ EDTA or citrate, and validated experimentally for $\mathrm{L}=$ DTPA as described in Supplementary Material Section 1. In all cases, no $\mathrm{Fe}$ (III) precipitation was expected to occur in the final solution on short timescales as the solubility product for amorphous ferric oxide (AFO) was not exceeded (see Supplementary Material Section 2 for calculations; in the absence of ligand AFO precipitation occurs rapidly at $2 \mu \mathrm{M} \mathrm{Fe}(\mathrm{III})$ at $\mathrm{pH} 8.2$ ).

Phth was not present when monitoring Fe(II) oxidation as both Phth and Phth-OH absorb strongly in the UV (interfering 
with the Fe(III)EDTA and Fe(III)DTPA absorbance) and also due to the formation of chemiluminescent Phth-OH (which interferes with luminol chemiluminescence).

\section{Fe(II) Oxidation in the Presence of Formate}

The oxidation of formate by $\mathrm{HO}^{\bullet}$ initially yields $\mathrm{CO}_{2}^{\bullet-}$, which reacts with $\mathrm{O}_{2}$ with a rate constant of $2 \times 10^{9} \mathrm{M}^{-1} \cdot \mathrm{s}^{-1}$ to yield $\mathrm{O}_{2}^{\bullet-}$ and $\mathrm{CO}_{2}$ (Buxton et al., 1976). As such, adding an excess of formate quantitatively converts all $\mathrm{HO}^{\bullet}$ that is produced to $\mathrm{O}_{2}^{\bullet-}$ and $\mathrm{CO}_{2}$. Under the standard reaction conditions used here, excess ligand effectively competes with $\mathrm{Fe}(\mathrm{II})$ for $\mathrm{HO}^{\bullet}$, forming ligand-derived organic radicals that are potentially able to influence $\mathrm{Fe}$ (II) oxidation kinetics. As the reactivity of these organic radicals is unknown, $\mathrm{Fe}(\mathrm{II})$ oxidation experiments were conducted with addition of sodium formate ([formate $]_{0}$ $=50 \mathrm{mM}$ for $\mathrm{L}=$ EDTA and DTPA and [formate $]_{0}=3 \mathrm{mM}$ for $\mathrm{L}=$ citrate) at formate concentrations sufficiently high for quantitative scavenging of $\mathrm{HO}^{\bullet}$, i.e., such that the reaction of $\mathrm{HO}^{\bullet}$ with excess ligand is rendered insignificant. When formate is present at these concentrations, all $\mathrm{HO}^{\bullet}$ will be converted to $\mathrm{O}_{2}^{\bullet-}$; if addition of formate does not change the reaction kinetics then this implies that excess ligand, the primary sink for $\mathrm{HO}^{\bullet}$ in the absence of formate, also reacts with $\mathrm{HO}^{\bullet}$ in a similar fashion as formate to ultimately yield $\mathrm{O}_{2}^{\bullet-}$, validating the assumption that the reaction of ligand with $\mathrm{HO}^{\bullet}$ can be simplified to a reaction that produces $\mathrm{O}_{2}^{\bullet-}$ along with some form of oxidized ligand.

\section{HO^ Production Experiments}

Experiments were performed at $22 \pm 2{ }^{\circ} \mathrm{C}$ in vessels shielded from light. Experiments were initiated by addition of $\mathrm{Fe}(\mathrm{II})$ $(2 \mu \mathrm{M})$ from an acidic stock $\left(4 \mathrm{mM} \mathrm{Fe} \mathrm{II}^{\mathrm{II}} \mathrm{SO}_{4} \cdot 7 \mathrm{H}_{2} \mathrm{O}\right.$ in $0.1 \mathrm{mM}$ $\mathrm{HCl})$ to a vigorously stirred solution containing $\mathrm{H}_{2} \mathrm{O}_{2}(0-$ $50 \mu \mathrm{M})$, Phth $(0.55 \mathrm{mM})$, and either no ligand, $1 \mathrm{mM}$ citrate, $10 \mu \mathrm{M}$ EDTA or $10 \mu \mathrm{M}$ DTPA. $\mathrm{HO}^{\bullet}$ formation was monitored using the phthalhydrazide method (Miller et al., 2011). Briefly, $\mathrm{HO}^{\bullet}$ reacts with $\mathrm{Phth}$ to form a hydroxyderivative (Phth-OH) that accumulates in solution. Phth-OH is subsequently quantified using chemiluminescence detection during oxidation in an FeLume flowcell (Waterville Analytical) employing $\mathrm{Cu}(\mathrm{III}) / \mathrm{H}_{2} \mathrm{O}_{2}$ as an oxidant in $0.5 \mathrm{M} \mathrm{Na} \mathrm{CO}_{3}$ buffer at $\mathrm{pH}$ 11. The term "Phth-OH" is used to represent the total amount of $\mathrm{HO}^{\bullet}$ that has reacted with $\mathrm{Phth}$, with the actual analyte, 5-hydroxy-2,3-dihydrophthalazine-1,4-dione (5$\mathrm{HO}-\mathrm{Phth}$ ), formed in approximately $20 \%$ yield (Miller et al., 2011).

\section{Impact of $t$-BuOH upon Phth-Trappable $\mathrm{HO} \cdot$ Production}

$\mathrm{HO}^{\bullet}$ production experiments were repeated in the presence of a range of $t-\mathrm{BuOH}$ concentrations $(2,5,20$, or $100 \mathrm{mM}$ ) with $0.55 \mathrm{mM}$ Phth present in each case to examine whether competition between $\mathrm{Phth}$ and $t-\mathrm{BuOH}$ was consistent with the known behavior of $\mathrm{HO}^{\bullet}$, thus supporting or refuting $\mathrm{HO}^{\bullet}$ formation. Experiments were performed with $5 \mu \mathrm{M} \mathrm{H}_{2} \mathrm{O}_{2}$ for $\mathrm{L}=\mathrm{EDTA}, 50 \mu \mathrm{M} \mathrm{H}_{2} \mathrm{O}_{2}$ for $\mathrm{L}=\mathrm{DTPA}$, and $10 \mu \mathrm{M} \mathrm{H}_{2} \mathrm{O}_{2}$ for $\mathrm{L}=$ citrate.

\section{Kinetic Modeling}

Experimental results were initially evaluated in the context of a basic kinetic model for $\mathrm{Fe}(\mathrm{II})$ oxidation in the presence of $\mathrm{L}$, $\mathrm{O}_{2}$, and $\mathrm{H}_{2} \mathrm{O}_{2}$, which we denote as the "Fe(II)L model," that was constructed using known reactions (Table 1). All rate constants were either taken directly from the literature or calculated from literature values, except for rate constants for the oxidation of $\mathrm{Fe}(\mathrm{II}) \mathrm{L}$ by $\mathrm{O}_{2}$ and the oxidation of $\mathrm{Fe}$ (II)L by $\mathrm{H}_{2} \mathrm{O}_{2}$, which were treated as variable parameters to be determined by fitting of the model to the experimental data. It was assumed in the $\mathrm{Fe}(\mathrm{II}) \mathrm{L}$ model that the reaction of $\mathrm{H}_{2} \mathrm{O}_{2}$ with $\mathrm{Fe}$ (II) (either inorganic or organically complexed) yielded $\mathrm{HO}^{\bullet}$; this was treated as a null hypothesis that was tested by attempting to fit the model to the experimental data. It was also assumed that, under the oxygenated experimental conditions employed, the reaction of $\mathrm{HO}^{\bullet}$ with $\mathrm{L}$ resulted in the oxidation of $\mathrm{L}$ to a compound $\mathrm{L}_{\mathrm{Ox}}$ that did not undergo further reaction, with concomitant formation of $\mathrm{O}_{2}^{\bullet-}$; this is expected for $\mathrm{L}=$ EDTA based on the mechanism established by Höbel and von Sonntag (1998) and hypothesized to also be the case for $\mathrm{L}=\mathrm{DTPA}$ or citrate. This assumption was tested by examining $\mathrm{Fe}$ (II)L oxidation in the presence of formate as described earlier. For experiments conducted in the presence of formate, the additional reactions in Table 2 were also included in the kinetic model.

Kinetic model simulations were performed using PrestoKinetics V 3.28.3 (Wulkow, 2004) and Kintecus V 4.1 (Ianni, 2003). All model fitting was performed using the routines available in Presto unless specified otherwise, in which case parameters were manually adjusted and the quality of fit assessed qualitatively using Kintecus simulations.

\section{RESULTS AND DISCUSSION}

\section{$\mathrm{HO}$ • Production by Inorganic $\mathrm{Fe}$ (II)}

When $\mathrm{Fe}(\mathrm{II})$ was oxidized by $\mathrm{H}_{2} \mathrm{O}_{2}$ in the absence of ligands, Phth-OH concentrations were always below the detection limit of $15 \mathrm{nM}$, implying no significant production of $\mathrm{HO}^{\bullet}$ occurred. This is despite $\mathrm{H}_{2} \mathrm{O}_{2}$ being the dominant oxidant of $\mathrm{Fe}$ (II) under these conditions (King and Farlow, 2000; González-Dávila et al., 2005; Santana-Casiano et al., 2006; Pham and Waite, 2008; Miller et al., 2009), with $\approx 1 \mu \mathrm{M}$ Phth-OH expected to form in this process if $\mathrm{HO}^{\bullet}$ was indeed the product of the $\mathrm{Fe}(\mathrm{II})-\mathrm{H}_{2} \mathrm{O}_{2}$ reaction. Control experiments confirmed that inorganic Fe(III) did not impact the recovery of 5-HO-Phth nor interfere with any other aspect of the method, confirming the result and suggesting that under the conditions of this study the $\mathrm{Fe}(\mathrm{II})-\mathrm{H}_{2} \mathrm{O}_{2}$ reaction, although the dominant oxidation path for $\mathrm{Fe}(\mathrm{II})$, does not yield $\mathrm{HO}^{\bullet}$. This result further supports the notion that a $\mathrm{pH}$ threshold exists above which the peroxidation of $\mathrm{Fe}(\mathrm{II})$ produces a species other than $\mathrm{HO}^{\bullet}$, the nature of which cannot be determined from this work, although likely to be some form of $\mathrm{Fe}(\mathrm{IV})$ compound (Hug and Leupin, 2003; Keenan and Sedlak, 2008; Bataineh et al., 2012; Lee et al., 2013).

\section{Kinetics of $\mathrm{Fe}$ (II) Oxidation and $\mathrm{HO}^{\circ}$ Production by Fe(II)EDTA and Fe(II)DTPA}

The oxidation kinetics of Fe(II)EDTA and Fe(II)DTPA were both well-described by the Fe(II)L model in Table 1 (see Figure 1). 
TABLE 1 | "Fe(II)L" kinetic model for Fe(II)L oxidation.

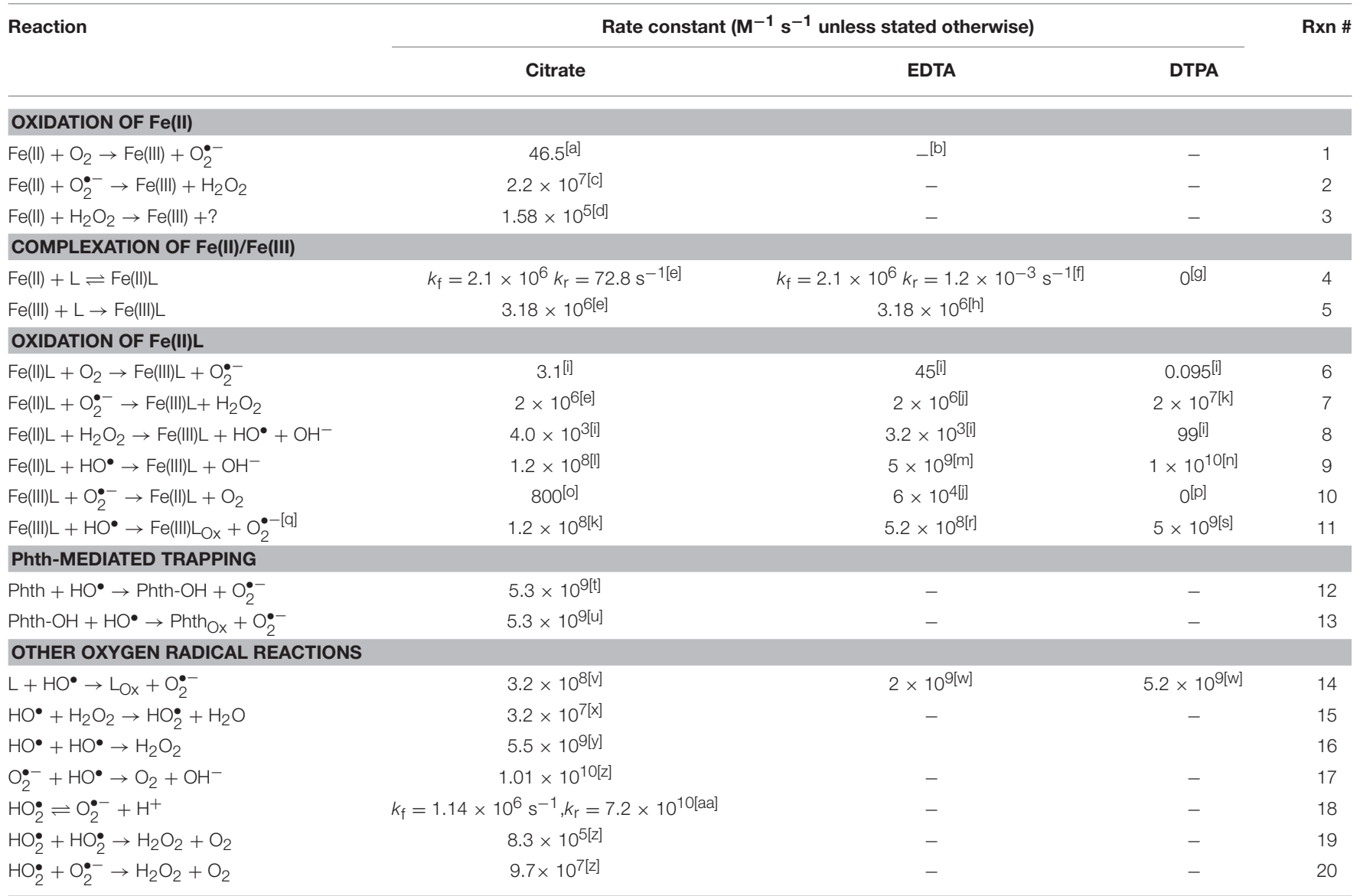

${ }^{[a]}$ Miller et al. (2009). [b] “-"indicates that the same rate constant was used for all ligands. ${ }^{[c]}$ Calculated using speciation model of King and Farlow (2000), ionic strength corrections performed using Davies Equation $\left(A=1.17, b=0.3, \ln \gamma=-A Z_{i}^{2}\left(I^{1 / 2} /\left(1+I^{1 / 2}\right)-b l\right)\right.$ and rate constants from Santana-Casiano et al. (2005), I $=0$. ${ }^{[0]}$ Rate doubled to reflect pseudo-first order rate constant from Miller et al. (2009); the stoichiometry is not explicitly considered to prevent speculation, although in this work it is not critical since $\mathrm{H}_{2} \mathrm{O}_{2}$ is typically in excess. ${ }^{[e]}$ Assumed to proceed at same rate as for EDTA with reverse rate constant calculated using the apparent overall formation constant of Fe(II)cit of log ${ }_{10}\left(K / M^{-1}\right)=4.46$ determined using speciation modeling (see Supplementary Material Section 3). [f] Taken from Fujii et al. (2011). ${ }^{[9]}$ Complexation not explicitly modeled as experimentally shown to be rapid. ${ }^{[h]}$ Fujiii et al. (2008). [" Fitted to data. "Determined by analysis of literature values, see discussion in text and Supplementary Material. ${ }^{[k]}$ Butler and Halliwell (1982). [" Taken from Zepp et al. (1992) for Fe(III)cit; Fe(II)cit assumed to react at a similar rate. ${ }^{[m]}$ Lati and Meyerstein (1978). [n] Rahhal and Richter (1989) demonstrated a ratio of 2:1 for rate constants for reactions between $\mathrm{HO}$ and Fe(II)DTPA/Fe(III)DTPA, rate constant for Fe(III)DTPA from Cabelli et al. (1989). [o] Garg et al. (2007) give $800 \mathrm{M}^{-1} \mathrm{~s}^{-1}$, Rose and Waite (2005) give $9 \times 10^{4}$, $\mathrm{M}^{-1} \mathrm{~s}^{-1}$; see text for discussion. [D] Reaction considered slow $\left(<10^{4} \mathrm{M}^{-1} \mathrm{~s}^{-1}\right.$. Buettner et al. (1983)) and as such was not included. [a] Nature of reaction is not established, especially at the low Fe(III)L concentrations used here. $\mathrm{HO}$ • initially oxidizes ligand by $\mathrm{H}$-abstraction, followed by either further oxidation by intra-molecular electron transfer (to yield Fe(II)L $\mathrm{Ox}$ ) or inter-

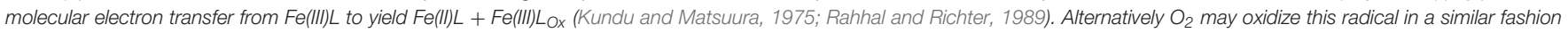

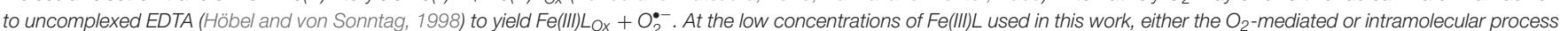

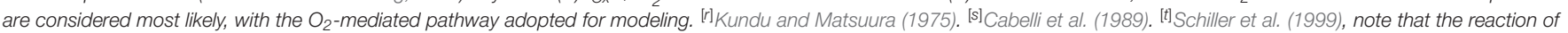
the intermediate cyclohexadienyl-type radical with $\mathrm{O}_{2}$ to yield $\mathrm{O}_{2}^{--}$via the Dorfman et al. (1962) mechanism is implicitly included. [u] assuming same rate constant as for reaction between $\mathrm{HO}^{\bullet}$ and Phth, although likely faster. ${ }^{[W]}$ Zepp et al. (1992) with the assumption that the initial organic radical formed is rapidly oxidized by $\mathrm{O}_{2}$ to yield $\mathrm{O}_{2}^{\bullet-}$, verified as discussed in text. ${ }^{[w]}$ Cabelli et al. (1989) for DTPA, Lati and Meyerstein (1978) for EDTA. It is assumed that the initial organic radical is subsequently oxidized to a diamagnetic species by $\mathrm{O}_{2}$, forming $\mathrm{O}_{2}^{--}$, with the work of Höbel and von Sonntag (1998) strongly suggesting this is the case for EDTA. ${ }^{[x]}$ Yu (2004). ["] Buxton et al. (1988). ${ }^{[2]}$ Bielski et al. (1985). [aa] Calculated using published value of reverse rate constant and $p K_{a}=4.8$

The kinetics of $\mathrm{Fe}(\mathrm{II}) \mathrm{L}$ oxidation ( $\mathrm{L}=\mathrm{EDTA}$ and DTPA) were unchanged in the presence of formate, supporting the formation of $\mathrm{O}_{2}^{\bullet-}$ during ligand oxidation by $\mathrm{HO}^{\bullet}$, as anticipated (Höbel and von Sonntag, 1998). It should be noted that bridged dimeric species of the form such as $\mathrm{Fe}(\mathrm{III}) \mathrm{L}\left(\mathrm{O}_{2}^{2-}\right) \mathrm{Fe}(\mathrm{III}) \mathrm{L}$, proposed to occur during $\mathrm{O}_{2}$-mediated oxidation by Seibig and Van Eldik (1997) for L = EDTA are not considered in the kinetic model as they are unimportant at the low $\mathrm{Fe}$ concentrations used here despite their demonstrated importance at millimolar concentrations of $\mathrm{Fe}(\mathrm{II})$ (Zang and Van Eldik, 1990b). The rate constants for $\mathrm{O}_{2}$ - and $\mathrm{H}_{2} \mathrm{O}_{2}$-mediated oxidation of $\mathrm{Fe}(\mathrm{II}) \mathrm{L}$ $(\mathrm{L}=$ EDTA, DTPA) found here are generally consistent with previously determined values under similar conditions (see Supplementary Material Sections 4 and 5 for details). For both oxidants, the oxidation of Fe(II)DTPA was an order of magnitude slower than that of $\mathrm{Fe}(\mathrm{II}) \mathrm{EDTA}$, despite the similar nature of these ligands, which is consistent with previous results (Graf et al., 1984). The absence of a readily-exchangeable bound water molecule in the Fe(II)DTPA complex (Zang and Van Eldik, 1990a) could explain the much slower oxidation kinetics 
observed for this complex if oxidation of Fe(II)L ( $\mathrm{L}=$ EDTA, DTPA) by $\mathrm{O}_{2}$ and $\mathrm{H}_{2} \mathrm{O}_{2}$ was an inner sphere process; in this case, with the initial binding of the oxidant to $\mathrm{Fe}$ (II)L being the rate-limiting step, exchange of a bound $\mathrm{H}_{2} \mathrm{O}$ molecule for an oxidant molecule should presumably proceed at a much greater rate and with less steric hindrance than would be observed when oxidant binding first requires breaking of an Fe(II)-chelate bond (Graf et al., 1984). Summers et al. (2008) have demonstrated the importance of the water-loss rate to the related superoxide-mediated reduction of Fe(III)EDTA and $\mathrm{Fe}(\mathrm{III}) \mathrm{DTPA}$.

For both Fe(II)EDTA and Fe(II)DTPA, significant Phthtrappable $\mathrm{HO}^{\bullet}$ production was observed. However, the interaction of the Fe-EDTA and Fe-DTPA complexes with $\mathrm{O}_{2}^{\bullet-}$ (which is formed from the reaction of $\mathrm{O}_{2}$ with $\mathrm{Fe}(\mathrm{II}) \mathrm{L}$ and also during oxidation of the hydroxycyclohexadienyl-radical resulting from the reaction of $\mathrm{HO}^{\bullet}$ and $\mathrm{Phth}$ ) complicates the kinetic modeling analysis. Although EDTA and DTPA are structurally quite similar, their Fe complexes exhibit markedly different reactivity with $\mathrm{O}_{2}^{\bullet-}$, likely due to the presence (EDTA) or absence (DTPA) of a readily exchangeable bound water molecule (Summers et al., 2008). Fe(III)DTPA is essentially unreactive with $\mathrm{O}_{2}^{\bullet-}$, with reported rate constants of $<10^{4}$ $\mathrm{M}^{-1} \mathrm{~s}^{-1}$ (Buettner et al., 1983) and $\approx 10^{3} \mathrm{M}^{-1} \mathrm{~s}^{-1}$ (Bolann et al., 1992), whereas $\mathrm{Fe}(\mathrm{II}) \mathrm{DTPA}$ is readily oxidized, with $k_{7}$

TABLE 2 | Additional reactions in the presence of formate.

\begin{tabular}{llc}
\hline Reaction & Rate constant & Rxn \# \\
\hline $\mathrm{HCOOH} \rightleftharpoons \mathrm{HCOO}^{-}+\mathrm{H}^{+}$ & $k_{\mathrm{f}}=1.78 \times 10^{6} \mathrm{~s}^{-1}$ & 21 \\
& $k_{\mathrm{r}}=10^{10} \mathrm{M}^{-1} \mathrm{~s}^{-1[\mathrm{a}]}$ & \\
$\mathrm{HO}+\mathrm{HCOOH} \rightarrow \mathrm{CO}_{2}+\mathrm{HO}_{2}^{\bullet}$ & $3.1 \times 10^{8} \mathrm{M}^{-1} \mathrm{~s}^{-1[\mathrm{~b}]}$ & 22 \\
$\mathrm{HO}+\mathrm{HCOO}^{-} \rightarrow \mathrm{CO}_{2}+\mathrm{O}_{2}^{\bullet-}$ & $3.2 \times 10^{9} \mathrm{M}^{-1} \mathrm{~s}^{-1[\mathrm{~b}]}$ & 23 \\
\hline
\end{tabular}

[a] Rate constant of $1010 \mathrm{M}^{-1} \mathrm{~s}^{-1}$ assumed for reaction with $\mathrm{H}+$; dissociation rate constant calculated using $\mathrm{pKa}=3.75$ from Duesterberg et al. (2005). [b] Rate constants taken from Kwan and Voelker (2002), implicitly includes the rapid further reaction of the initially formed $\mathrm{CO}_{2}^{\cdot-}$ with $\mathrm{O}_{2}$ to yield $\mathrm{CO}_{2}$ and $\mathrm{HO}_{2}^{*} / \mathrm{O}_{2}^{--}$, which is the only significant pathway under the conditions of this study.
$=2 \times 10^{7} \mathrm{M}^{-1} \mathrm{~s}^{-1}$ (Butler and Halliwell, 1982), such that $\mathrm{O}_{2}^{\bullet-}$ acts only as an oxidant and $\mathrm{Fe}$ redox cycling does not occur. In contrast, $\mathrm{Fe}(\mathrm{II})$ EDTA is readily oxidized by $\mathrm{O}_{2}^{\bullet-}$, with $k_{7} \approx 2-8 \times 10^{6} \mathrm{M}^{-1} \mathrm{~s}^{-1}$ (Ilan and Czapski, 1977; Bull et al., $1982,1983)$, with $k_{7}=2 \times 10^{6} \mathrm{M}^{-1} \mathrm{~s}^{-1}$ appropriate under the conditions of this study (see Supplementary Material Section 6 for further discussion). Unlike DTPA, Fe(III) complexed by EDTA is readily reduced by $\mathrm{O}_{2}^{\bullet-}, k_{10}=10^{3}-10^{7} \mathrm{M}^{-1} \mathrm{~s}^{-1}$ (Bull et al., 1983). The wide range of reported values for the reduction rate constant is due to significant media/ionic strength effects (due to changes in the thermodynamics of the speciation and because the reaction involves two likecharged ions with $z=-1$ ) and also a $\mathrm{pH}$ effect as only the $\left[\mathrm{Fe}^{\mathrm{III}}(\mathrm{EDTA})\left(\mathrm{H}_{2} \mathrm{O}\right)\right]^{-}$form is reactive with $\mathrm{O}_{2}^{\bullet-}$; the hydrolyzed complex $\left[\mathrm{Fe}^{\mathrm{III}}(\mathrm{EDTA})(\mathrm{OH})\right]^{2-}$ is essentially unreactive, with the $\mathrm{p} K_{\mathrm{a}}$ for $\left[\mathrm{Fe}^{\mathrm{III}}(\mathrm{EDTA})\left(\mathrm{H}_{2} \mathrm{O}\right)\right]^{-} \approx 7.6$ (Bull et al., 1983). As the current work was conducted at $\mathrm{pH} 8.2$, near the $\mathrm{p} K_{\mathrm{a}}$ of $\mathrm{Fe}(\mathrm{III}) \mathrm{EDTA}$, it is difficult to obtain a reliable literature estimate for the reduction rate constant. From a compilation of literature rate constants (discussed further in the Supplementary Material Section 6), a value for $k_{10}$ of between $2 \times 10^{4}$ and $6 \times 10^{5}$ $\mathrm{M}^{-1} \mathrm{~s}^{-1}$ is considered appropriate. Using the kinetic model it was shown that significant redox cycling of Fe occurs when $k_{10}$ is at the upper end of this range, but not at the lower end. This $\mathrm{Fe}$ redox cycling results in elevated $\mathrm{Fe}$ (II) concentrations at later stages of the reaction; although this has negligible impact upon the kinetics of $\mathrm{Fe}(\mathrm{II})$ oxidation, when $\mathrm{H}_{2} \mathrm{O}_{2}$ is present in excess of $\mathrm{Fe}$, this continual flux of $\mathrm{Fe}(\mathrm{II}) \mathrm{EDTA}$ results in ongoing $\mathrm{HO}^{\bullet}$ production even after the oxidation of Fe(II)EDTA appears to be complete (see Supplementary Figures 4, 5 in the Supplementary Material). Such an ongoing production of $\mathrm{HO}^{\bullet}$ is not supported by the data, suggesting the value for $k_{10}$ appropriate to the conditions of study is at the lower end of the possible range.

It is clear that the behavior of the system, especially with regards to the kinetics and magnitude of $\mathrm{HO}^{\bullet}$ production, is strongly influenced by the interaction of Fe-EDTA complexes with $\mathrm{O}_{2}^{\bullet-}$. The sensitivity of the system to the rate constant for reduction of $\mathrm{Fe}$ (III)EDTA by $\mathrm{O}_{2}^{\bullet-}$ is not evident when examining
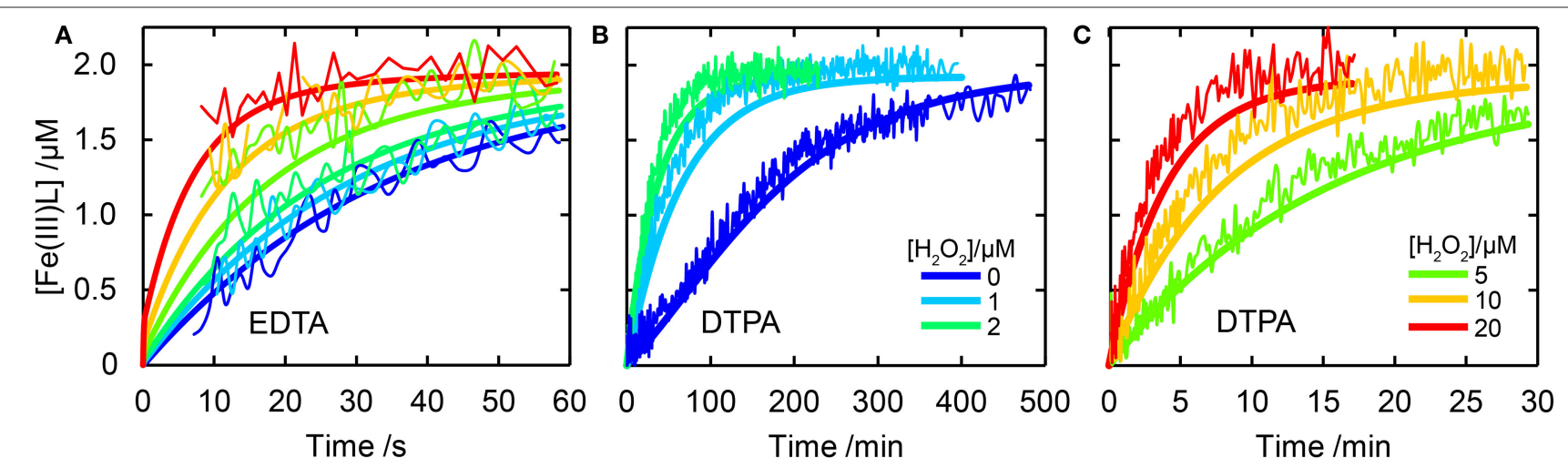

FIGURE 1 | Comparison of experimental data to model results for Fe(II)EDTA and Fe(III)EDTA oxidation studies. In all cases thin lines are experimental data and thick lines model output. Experimental conditions were $[\mathrm{Fe}(\mathrm{II})]_{0}=2 \mu \mathrm{M}$ and $[\mathrm{EDTA}$ or DTPA $]=10 \mu \mathrm{M}$. Panel (A) shows results for EDTA for $\left[\mathrm{H}_{2} \mathrm{O}_{2}\right]=0(\mathrm{blue}), 1$, $2,5,10$, and $20 \mu \mathrm{M}$ (red). Panel (B,C) show results for DTPA with $\left[\mathrm{H}_{2} \mathrm{O}_{2}\right]$ as labeled. 
Fe(II) oxidation kinetics alone, and highlights the need to carefully consider the fate of the reactive intermediates. Due to the sensitivity of the model to the magnitude of $k_{10}$, several values of this rate constant were trialed within the plausible bounds determined from previous studies, and the magnitude of the $\mathrm{O}_{2}$ and $\mathrm{H}_{2} \mathrm{O}_{2}$-mediated oxidation rate constants then fitted to the data. From this process a value for $k_{10}$ of $6 \times 10^{4} \mathrm{M}^{-1} \mathrm{~s}^{-1}$ was found to both adequately describe the data and lie within the range expected from previous studies. After accounting for the complications introduced by reactions involving $\mathrm{O}_{2}^{\bullet-}$, both the Fe-EDTA and Fe-DTPA systems were well described by a kinetic model that proposed $\mathrm{HO}^{\bullet}$ as the sole-product of the reaction between $\mathrm{H}_{2} \mathrm{O}_{2}$ and $\mathrm{Fe}(\mathrm{II}) \mathrm{L}$ ( $\mathrm{L}=$ EDTA, DTPA), as can be seen in Figures 2, 3. The ability to describe all the experimental results using the kinetic model developed demonstrates that there is no need to invoke higher-valent Fe species when $\mathrm{L}=$ EDTA or DTPA, and the hypothesis that quantitative formation of $\mathrm{HO}^{\bullet}$ occurs in this system is not inconsistent with the observed behavior.

Experiments with the addition of $t-\mathrm{BuOH}(0,2,5,20$, $100 \mathrm{mM})$, which competes with Phth $(0.55 \mathrm{mM})$ for $\mathrm{HO}^{\bullet}$ via a well-described mechanism ( $R x n 12$ in Table 1; see Supplementary Material Section 7 for the reactions of $t-\mathrm{BuOH}$ ), were used to validate that $\mathrm{HO}^{\bullet}$ was the species trapped by Phth. The final Phth-OH concentration was determined from both the experimental data and model predictions, then the impact of $t$ $\mathrm{BuOH}$ assessed by fitting a standard competition equation to the data:

$$
[\text { Phth }-\mathrm{OH}]=\frac{[\text { Phth }-\mathrm{OH}]_{\infty}}{1+R \frac{[t-\mathrm{BuOH}]}{[\mathrm{Phth}]}}
$$

where $[\mathrm{Phth}-\mathrm{OH}]_{\infty}$ is the final Phth-OH concentration in the absence of $t-\mathrm{BuOH}$ and $R$ is the ratio of the rate constants for reaction of $\mathrm{HO}^{\bullet}$ with $t-\mathrm{BuOH}$ and $\mathrm{Phth}$, i.e., $k(\mathrm{HO})^{\bullet} t$ $\mathrm{BuOH}) / k\left(\mathrm{HO}^{\bullet}, \mathrm{Phth}\right)$. The value of $R$ was calculated for both the experimental data and also the kinetic model prediction; agreement between both values provides additional evidence for $\mathrm{HO}^{\bullet}$ production. For $\mathrm{L}=\mathrm{EDTA}$, the experimental data yielded $R=0.117 \pm 0.003$, in good agreement with $R=0.107 \pm$ 0.001 obtained from fitting the competition equation to kinetic model output. For $\mathrm{L}=$ DTPA the experimental data yielded $R=0.073 \pm 0.007$ which is also in good agreement with $R=0.089 \pm 0.002$ obtained from the kinetic model output (in all cases $R$ is given as best fit value \pm one standard error from the curve fitting procedure, which likely underestimates the true uncertainty). For each ligand, the kinetic model output value of $R$ differed from the value of 0.11 predicted from literature constants (Buxton et al., 1988; Schiller et al., 1999) due to the more complicated interactions present in the kinetic models compared to the assumptions made in the simplified competition equation; however, in both cases, the results are consistent with $\mathrm{HO}^{\bullet}$ as the only source of Phth-OH in this system. While Rahhal and Richter (1988) have previously asserted that the product of the $\mathrm{Fe}(\mathrm{II}) \mathrm{DTPA}-\mathrm{H}_{2} \mathrm{O}_{2}$ reaction is completely unreactive with $t$ $\mathrm{BuOH}$, our results clearly demonstrate that the product of this reaction does react with $t-\mathrm{BuOH}$ in a manner quantitatively consistent with the product being $\mathrm{HO}^{\bullet}$.

\section{Kinetics of $\mathrm{Fe}$ (II) Oxidation and $\mathrm{HO}^{\bullet}$ Production by $\mathrm{Fe}$ (II)Citrate}

The apparent rate of $\mathrm{H}_{2} \mathrm{O}_{2}$-mediated $\mathrm{Fe}(\mathrm{II})$-citrate oxidation varied with $\mathrm{Fe}$ (II) concentration. This dependence could not be reproduced by the $\mathrm{Fe}(\mathrm{II}) \mathrm{L}$ model in Table 1, which fitted the data poorly (Figure 4). Attempts to fit this model simultaneously to the $\mathrm{Fe}(\mathrm{II})$ oxidation and $\mathrm{HO}^{\bullet}$ production data were also unsuccessful. Due to the inability of the $\mathrm{Fe}(\mathrm{II}) \mathrm{L}$ model to reproduce the $\mathrm{Fe}$ (II) concentration dependence, and given that $\mathrm{HO}^{\bullet}$ production experiments were only conducted with $[\mathrm{Fe}(\mathrm{II})]_{0}$ $=2 \mu \mathrm{M}$, a second model scenario was examined in which the kinetic model in Table 1 was fitted to the $\mathrm{HO}^{\bullet}$ production data (which was conducted with $[\mathrm{Fe}(\mathrm{II})]_{0}=2 \mu \mathrm{M}$ ) and also only to the oxidation data where $[\mathrm{Fe}(\mathrm{II})]_{0}=2 \mu \mathrm{M}$. This fitting scenario, which we denote as the "Fe(II)L-2 $\mu \mathrm{M}$ " model, also yielded poor
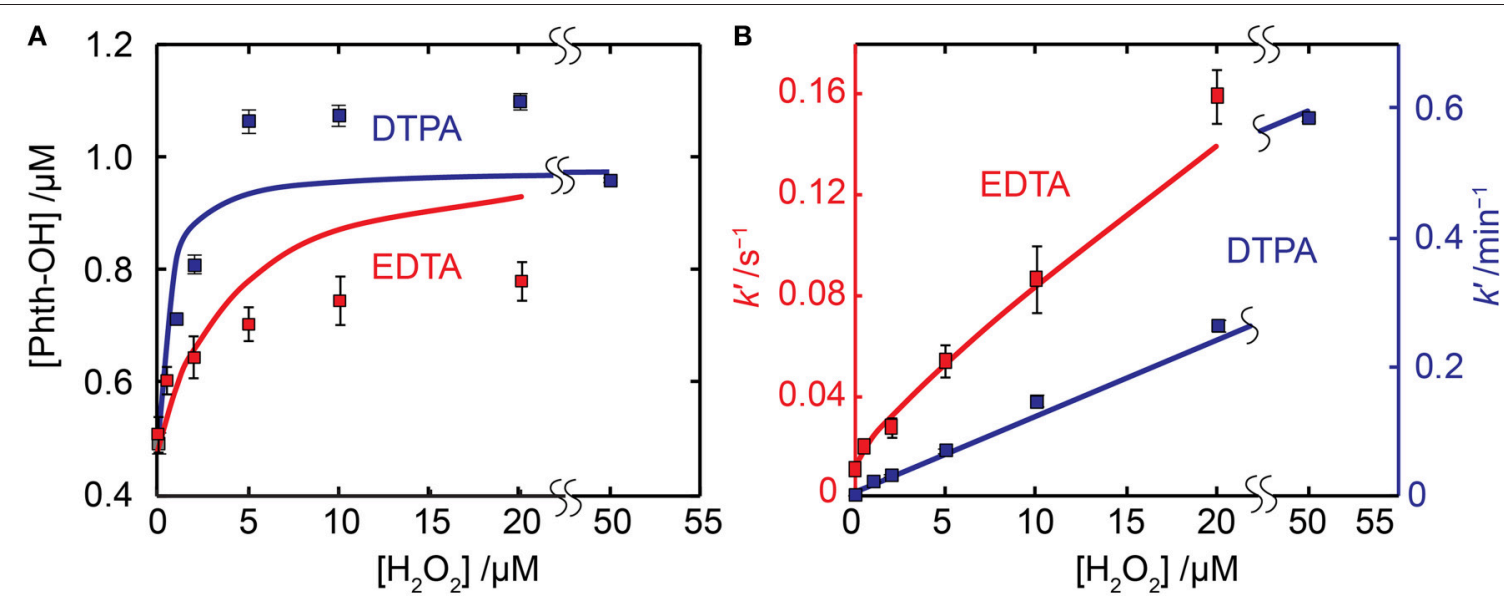

FIGURE 2 | Comparison of experimental and model results for the magnitude (A) and pseudo-first order rate constant (B) of Phth-OH production for $\mathbf{L}=\mathbf{E D T A}$ and DTPA. Experimental data are shown as symbols in all panels with the model results shown as solid lines. In all cases $[\text { Fe(II) }]_{0}=2 \mu \mathrm{M}$ and $[\mathrm{L}]=10 \mu \mathrm{M}$. 

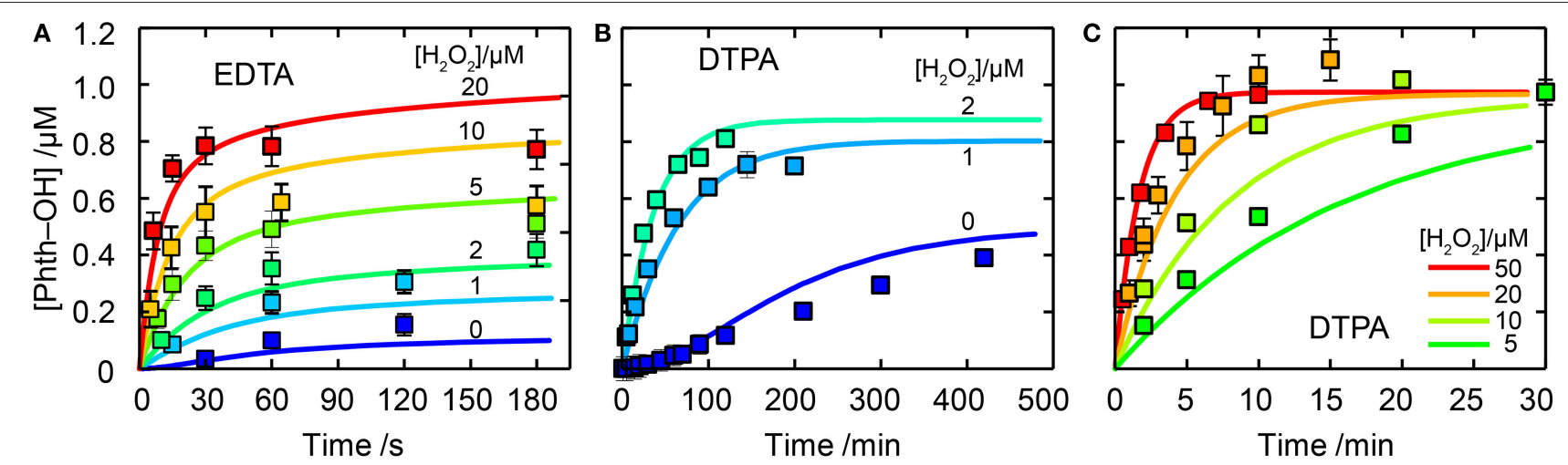

FIGURE 3 | Phth-OH production by Fe(II)EDTA (A) and Fe(II)DTPA (B,C). Experimental data are shown as symbols with error bars the standard deviation of three replicate experiments. Kinetic model results are shown as solid lines (with $k_{10}=6 \times 10^{4} \mathrm{M}^{-1} \mathrm{~s}^{-1}$ for EDTA). In all cases [Fe(II)] $=2 \mu \mathrm{M}$, [L] $=10 \mu \mathrm{M}$ and $\left[\mathrm{H}_{2} \mathrm{O}_{2}\right]$ is as labeled.
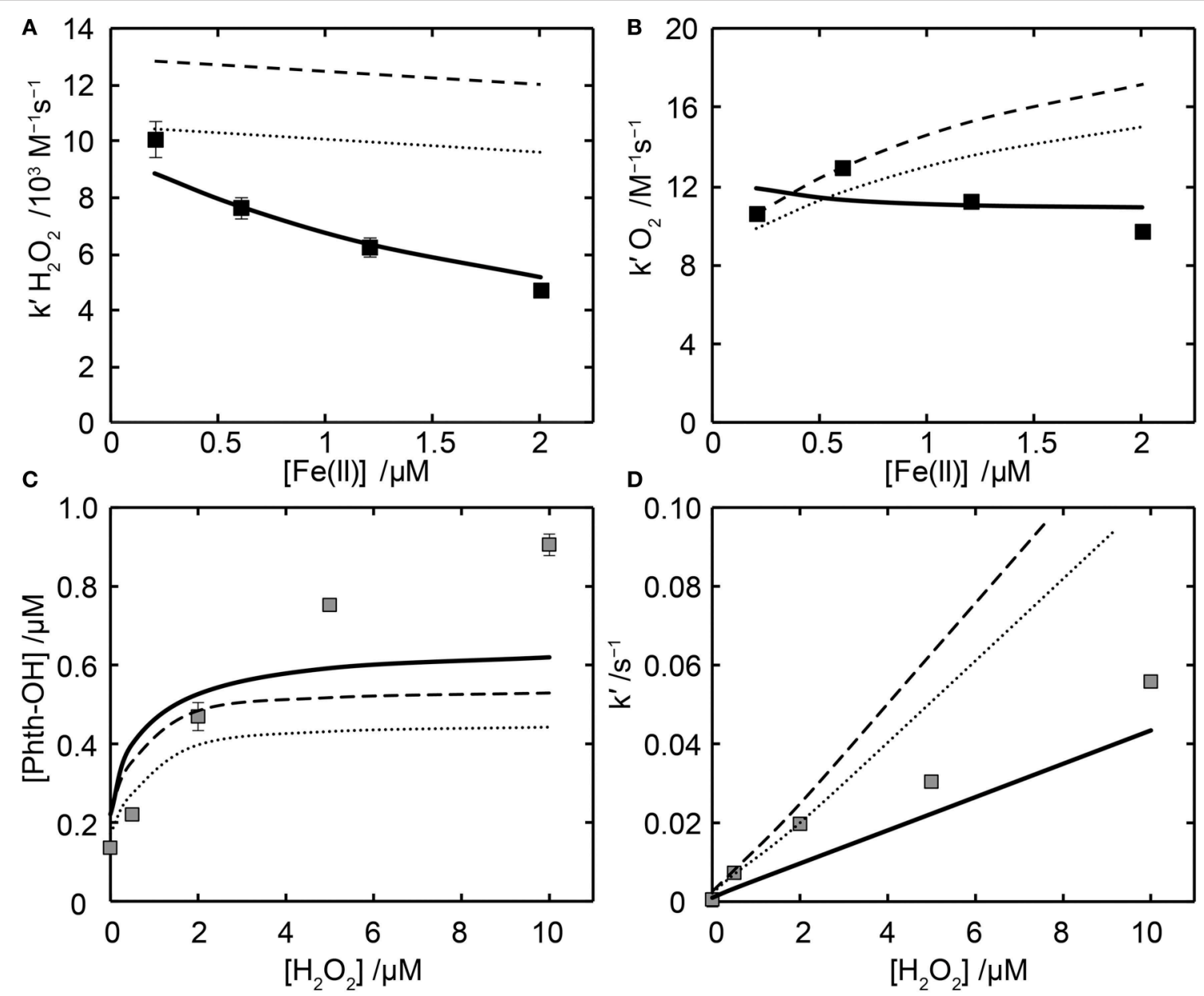

FIGURE 4 | Kinetics of Fe(II) oxidation and resulting Phth-OH production in the presence of citrate. Panels (A,B) show the apparent rate constants for $\mathrm{Fe}(\mathrm{II})$-citrate oxidation by $\mathbf{( A )} \mathrm{H}_{2} \mathrm{O}_{2}$ and (B) $\mathrm{O}_{2}$ as a function of initial Fe(II) concentration ([cit] = 1 mM in all cases). Symbols are derived from linear fits of experimental pseudo-first order oxidation rate constants as a function of $\left[\mathrm{H}_{2} \mathrm{O}_{2}\right] \mathbf{( A )}$ or from the pseudo-first order rate constant divided by $\left[\mathrm{O}_{2}\right]$ (B). Panels (C,D) show $\mathrm{HO}^{\bullet}$ production, with panel (C) showing the magnitude of total Phth- $\mathrm{OH}$ production when $[\mathrm{Fe}(\mathrm{II})]_{0}=2 \mu \mathrm{M}$ and panel (D) showing the kinetics of Phth-OH formation (the pseudo-first order rate constant of Phth-OH production). In all panels model predictions are indicated by lines, with the Fe(II)L model shown as a dashed line, the $\mathrm{Fe}(\mathrm{II}) \mathrm{L}-2 \mu \mathrm{M}$ model as a dotted line and the Fe(II) ${ }_{2} \mathrm{~L}$ model as a solid line. 
results. The failure of the $\mathrm{Fe}(\mathrm{II}) \mathrm{L}$ model, which only considers one form of $\mathrm{Fe}(\mathrm{II})$-cit species, is not surprising, as the most likely reason for a concentration dependence of the oxidation rate is the formation of higher-order complexes, which will lead to speciation being a function of the $\mathrm{Fe}(\mathrm{II})$ concentration as well as the $\mathrm{Fe}(\mathrm{II})$ :cit ratio.

None-the-less, several possible explanations were considered for the poor performance of this model. The possibility of organic radicals reducing $\mathrm{Fe}(\mathrm{III}) \mathrm{L}$ was discarded since the rate constant for reaction between carbon-centered radicals and $\mathrm{O}_{2}$, which is typically near $2 \times 10^{9} \mathrm{M}^{-1} \mathrm{~s}^{-1}$ (von Sonntag et al., 1997), is likely much greater than that for the reaction of carbon centered radicals with $\mathrm{Fe}(\mathrm{III})$ cit; reported rate constants for reduction of inorganic $\mathrm{Fe}(\mathrm{III})$ by hydroxyalkyl radicals are (1-6) $\times 10^{8} \mathrm{M}^{-1} \mathrm{~s}^{-1}$ (Neta et al., 1996). Formate addition experiments further supported the assumption that $\mathrm{O}_{2}$ was the main sink for carbon-centered radicals, as its presence did not alter the $\mathrm{Fe}(\mathrm{II})$ oxidation results. The reaction of organic radicals with $\mathrm{O}_{2}$ is likely to ultimately yield $\mathrm{O}_{2}^{\bullet-}$, which may oxidize or reduce iron. Garg et al. (2007) reported a rate constant for $\mathrm{O}_{2}^{\circ-}$ mediated reduction of $\mathrm{Fe}(\mathrm{III})$ cit of $800 \mathrm{M}^{-1} \mathrm{~s}^{-1}$, which is likely to be applicable under the current conditions based upon the kinetic model presented in their work. Assuming that the rate constant for $\mathrm{O}_{2}^{\bullet-}$-mediated oxidation of $\mathrm{Fe}(\mathrm{II})$ cit is similar to that of Fe(II)EDTA $\left(2 \times 10^{6} \mathrm{M}^{-1} \mathrm{~s}^{-1}\right), \mathrm{O}_{2}^{--}$will be a net oxidant. This reasoning was supported by the $\mathrm{HO}^{\bullet}$ trapping experiments, in which a limiting Phth-OH concentration of $\approx 1 \mu \mathrm{M}$ (which is half the initial $\mathrm{Fe}(\mathrm{II})$ concentration) was obtained at high $\left[\mathrm{H}_{2} \mathrm{O}_{2}\right]$. This limit occurs because $\mathrm{O}_{2}^{\bullet-}$ formed during the $\mathrm{HO}^{\bullet}$ Phth reaction oxidizes $\mathrm{Fe}(\mathrm{II}) \mathrm{cit}$, hence limiting the amount of $\mathrm{Fe}(\mathrm{II})$ cit that is able to react with $\mathrm{H}_{2} \mathrm{O}_{2}$. If $\mathrm{O}_{2}^{--}$was also able to effectively reduce $\mathrm{Fe}(\mathrm{III})$ cit complexes, such an effect would not be observed, and enhanced Phth-OH production would be expected as a result of this additional flux of Fe(II)cit. This conclusion is consistent with the results of Sutton (1985) who employed similar logic to formate degradation studies. Even if a higher rate constant for $\mathrm{O}_{2}^{--}$-mediated reduction was used in the modeling [e.g., $9 \times 10^{4} \mathrm{M}^{-1} \mathrm{~s}^{-1}$ from Rose and Waite (2005) which was determined at lower citrate:Fe ratios than those used here] it was still not possible to replicate the trends observed. As such, it can be deduced that reactions of $\mathrm{O}_{2}^{\bullet-}$ are unable to account for the apparent $\mathrm{Fe}(\mathrm{II})$ cit concentration dependence.

The trends observed can be reproduced if the existence of a diiron citrate species of the form $\mathrm{Fe}(\mathrm{II})_{2} \mathrm{~L}$ is proposed with differing oxidation kinetics to $\mathrm{Fe}(\mathrm{II}) \mathrm{L}$ [termed the " $\mathrm{Fe}(\mathrm{II})_{2} \mathrm{~L}$ " model, which includes the additional reactions shown in Table 3]. The oxidation data could only poorly constrain parameters in the $\mathrm{Fe}(\mathrm{II})_{2} \mathrm{~L}$ model, with Presto unable to converge to a unique solution. As such, an analytical expression was used to fit the $\mathrm{Fe}(\mathrm{II})_{2} \mathrm{~L}$ complexation constants $\left(K_{4}\right.$ and $\left.K_{24}\right)$ to the data (see Supplementary Material Section 8 for details; note that the related formation constants, $\beta_{M, L}$ are also referred to, with $\beta_{1,1}=$ $K_{4}$ and $\left.\beta_{2,1}=K_{4} K_{24}\right)$. Provided that $\log K_{4}>4$ and $\log$ $K_{24} \approx \log K_{4}+3.1$, it was possible to find values for the $\mathrm{Fe}(\mathrm{II}) \mathrm{L}$ oxidation rate constant that fitted the data well. The physical basis for this lower bound on $K_{4}$ being that small
TABLE 3 | Additional reactions used in the $\mathrm{Fe}(\mathrm{II})_{2} \mathrm{~L}$ model.

\begin{tabular}{lcc}
\hline Reaction & $\begin{array}{c}\text { Rate constant } \\
\left(\mathbf{M}^{-1} \mathbf{s}^{-1} \mathbf{)}\right.\end{array}$ & Rxn \# \\
\hline $\mathrm{Fe}(I I) \mathrm{L}+\mathrm{Fe}(\mathrm{II}) \rightleftharpoons \mathrm{Fe}(\mathrm{II})_{2} \mathrm{~L}$ & $\begin{array}{c}k_{\mathrm{f}}=10^{10} \\
\mathrm{k}_{\mathrm{r}}=128 \mathrm{~s}^{-1[\mathrm{a}]}\end{array}$ & 24 \\
$\mathrm{Fe}(\mathrm{II})_{2} \mathrm{~L}+\mathrm{O}_{2} \rightarrow \mathrm{Fe}(\mathrm{II})+\mathrm{Fe}(\mathrm{III}) \mathrm{L}+\mathrm{O}_{2}^{\bullet-[\mathrm{b}]}$ & $3.9^{[\mathrm{c}]}$ & 25 \\
$\mathrm{Fe}(\mathrm{II})_{2} \mathrm{~L}+\mathrm{O}_{2}^{\bullet-} \rightarrow \mathrm{Fe}(\mathrm{II})+\mathrm{Fe}(\mathrm{III}) \mathrm{L}+\mathrm{H}_{2} \mathrm{O}_{2}^{[\mathrm{b}]}$ & $3 \times 10^{6[\mathrm{~d}]}$ & 26 \\
$\mathrm{Fe}(\mathrm{II})_{2} \mathrm{~L}+\mathrm{H}_{2} \mathrm{O}_{2} \rightarrow \mathrm{Fe}(\mathrm{II})+\mathrm{Fe}(\mathrm{III}) \mathrm{L}+\mathrm{HO}^{\bullet}+\mathrm{OH}^{-[\mathrm{b}]}$ & ${ }_{1}^{[\mathrm{e}]}$ & 27 \\
$\mathrm{Fe}(\mathrm{II})_{2} \mathrm{~L}+\mathrm{HO}^{\bullet} \rightarrow \mathrm{Fe}(\mathrm{II})+\mathrm{Fe}(\mathrm{II}) \mathrm{L}+\mathrm{OH}^{-[\mathrm{b}]}$ & $1.2 \times 10^{8[\mathrm{~d}]}$ & 28
\end{tabular}

[a] Values for $\log K_{4}=4.75, \log K_{4} K_{24}=12.6$ and assuming rapid reaction, i.e., $K_{f}$ for both complexation steps set at $10^{10} \mathrm{M}^{-1} \mathrm{~s}^{-1}$, see text for further discussion. [b] Each oxidant assumed to oxidize one molecule of iron only, with remaining Fe(II) re-equilibrating with the $\mathrm{Fe}(I)$ pool. [c] As fitted to data by fitting the $\mathrm{O}_{2}$ oxidation data using Presto and manually adjusting $k_{8}$ until good agreement between apparent $\mathrm{H}_{2} \mathrm{O}_{2}$-mediated oxidation rates achieved. [d] Same rate constant assumed as for $\mathrm{Fe}(I I) L$. [e] Good fits achieved so long as $\mathrm{Fe}(\mathrm{Il})_{2} \mathrm{~L}$ is comparatively unreactive, see text for discussion.

amounts of inorganic $\mathrm{Fe}(\mathrm{II})$ have low impact, so as long as the majority of $\mathrm{Fe}(\mathrm{II})$ is in complexed form, the results will be similar. In all cases a good fit could only be achieved if it was assumed that $\mathrm{Fe}(\mathrm{II})_{2} \mathrm{~L}$ was comparatively unreactive (i.e., apparent $\mathrm{H}_{2} \mathrm{O}_{2}$-mediated oxidation rate constant $<10^{3}$ $\mathrm{M}^{-1} \mathrm{~s}^{-1}$, with a value of $1 \mathrm{M}^{-1} \mathrm{~s}^{-1}$ adopted for modeling). A value of $\log K_{4}=4.75$ was determined from fitting to the $\mathrm{HO}^{\bullet}$ production data, with $\log K_{24}$ then fixed from the analytical modeling process. As is apparent in Figures 4A,B, only the $\mathrm{Fe}(\mathrm{II})_{2} \mathrm{~L}$ model was able to provide a good fit to the $\mathrm{Fe}(\mathrm{II})$ cit oxidation data under all conditions. The $\mathrm{Fe}(\mathrm{II})_{2} \mathrm{~L}$ species is speculative and does not accord with the speciation model of Königsberger et al. (2000), with published formation constants of similar species from other proposed models e.g., $\mathrm{Fe}(\mathrm{II})_{2}(\mathrm{cit})_{2}(\mathrm{OH})_{2}^{4-}$ from Amico et al. (1979), also inconsistent with those required to reproduce the data here. Inclusion of the proposed species is considered justified however due to the general uncertainty surrounding $\mathrm{Fe}(\mathrm{II})$-citrate speciation at the high $\mathrm{pH}$ of this work, and that inclusion of this species was able to describe the data well, while all other possibilities considered failed to do so. This issue is explored further in Supplementary Material Section 9.

Peroxidation of $\mathrm{Fe}(\mathrm{II})$ in the presence of citrate resulted in substantial $\mathrm{HO}^{\bullet}$ production. The apparent rate constant for reaction with $\mathrm{H}_{2} \mathrm{O}_{2}$ of $(4.9 \pm 0.4) \times 10^{3} \mathrm{M}^{-1} \mathrm{~s}^{-1}$ was determined from the Phth-OH production data (assuming quantitative formation of $\mathrm{HO}^{\bullet}$ ); this compares to an apparent rate constant of $(4.7 \pm 0.2) \times 10^{3} \mathrm{M}^{-1} \mathrm{~s}^{-1}$ for the $\mathrm{H}_{2} \mathrm{O}_{2}$-mediated oxidation of $\mathrm{Fe}(\mathrm{II})$ cit when $[\mathrm{Fe}(\mathrm{II})]_{0}=2 \mu \mathrm{M}$ (i.e., under comparable conditions to the $\mathrm{HO}^{\bullet}$ production experiments). The close correspondence between these rate constants provides evidence that the production of $\mathrm{HO}^{\bullet}$ is closely coupled to the reaction of $\mathrm{H}_{2} \mathrm{O}_{2}$ with $\mathrm{Fe}(\mathrm{II}) \mathrm{cit}$, and that it is likely that $\mathrm{HO}^{\bullet}$ is the sole product of this reaction. Competition experiments with $t$ - $\mathrm{BuOH}$ supported the conclusion that $\mathrm{HO}^{\bullet}$ is the only species trapped by Phth in the $\mathrm{Fe}(\mathrm{II})$-citrate system, with experiments yielding a value of $R=0.088 \pm 0.004$, in good agreement with predicted values of $R=0.078,0.085$, and 0.088 for the $\mathrm{Fe}(\mathrm{II})_{2} \mathrm{~L}$ model, the $\mathrm{Fe}(\mathrm{II}) \mathrm{L}$ model, and the $\mathrm{Fe}(\mathrm{II}) \mathrm{L}-2 \mu \mathrm{M}$ model, respectively. 

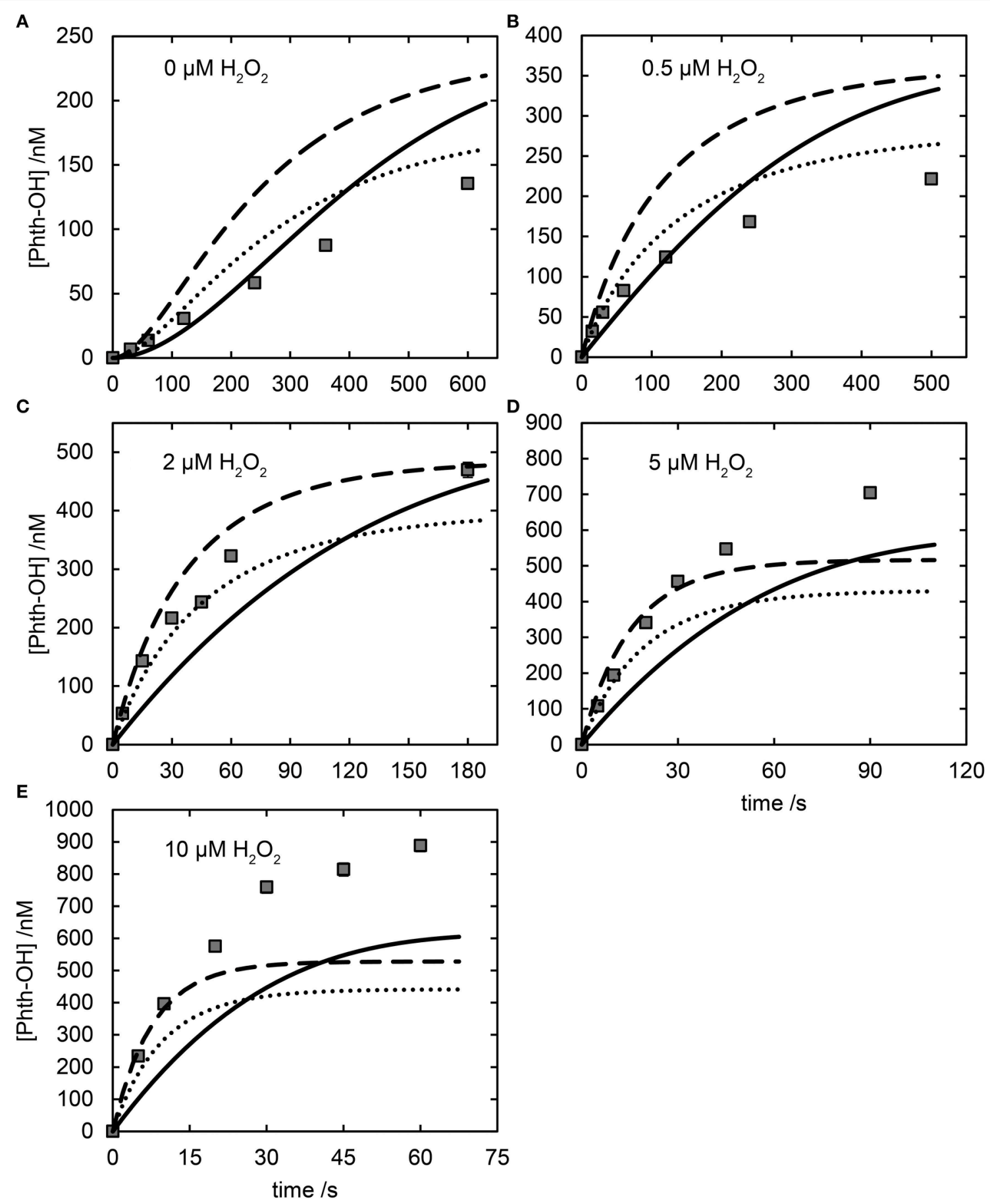

FIGURE 5 | Comparison of experimental data and model results for $\mathrm{HO}^{\bullet}$ production by $\mathrm{Fe}(\mathrm{II})$ cit when oxidized by $\mathrm{H}_{2} \mathrm{O}_{2}\left(\mathbf{0}-10 \mu \mathrm{M}_{\text {, }}\right.$ panels A-E respectively). In all panels $[\mathrm{Fe}(\mathrm{II})]=2 \mu \mathrm{M}$, [cit] $=1 \mathrm{mM}$, experimental data are shown as symbols, the Fe(II)L model as a dashed line, the Fe(II)L-2 $\mu \mathrm{M}$ model as a dotted line and the $\mathrm{Fe}(\mathrm{II})_{2} \mathrm{~L}$ model as a solid line.

However, the $\mathrm{Fe}(\mathrm{II}) \mathrm{L}, \mathrm{Fe}(\mathrm{II}) \mathrm{L}-2 \mu \mathrm{M}$, and the $\mathrm{Fe}(\mathrm{II})_{2} \mathrm{~L}$ models all provided a poor fit to the experimental $\mathrm{HO}^{\bullet}$ production data (see Figures 4C,D, 5). Although this may suggest that $\mathrm{HO}^{\bullet}$ is not the sole product of the $\mathrm{Fe}(\mathrm{II}) \mathrm{cit}-\mathrm{H}_{2} \mathrm{O}_{2}$ interaction, it is far more likely that the poor fit is due to inadequacies in all the models described and that $\mathrm{HO}^{\bullet}$ is still likely the dominant product. As shown above for $\mathrm{L}=$ EDTA, without a thorough understanding of the oxidation and reduction kinetics of $\mathrm{Fe}(\mathrm{II}) \mathrm{L} / \mathrm{Fe}$ (III)L by $\mathrm{O}_{2}, \mathrm{O}_{2}^{\bullet-}$, and $\mathrm{H}_{2} \mathrm{O}_{2}$ it is difficult to quantitatively determine whether $\mathrm{HO}^{\bullet}$ is the exclusive intermediate from the reaction 
of $\mathrm{Fe}(\mathrm{II}) \mathrm{L}$ and $\mathrm{H}_{2} \mathrm{O}_{2}$. It is clear that existing models of $\mathrm{Fe}(\mathrm{II})$ citrate speciation and oxidation are not sufficiently refined to definitively rule out the presence of additional oxidative species, with additional work needed to better understand the $\mathrm{Fe}(\mathrm{II})$-citrate $-\mathrm{H}_{2} \mathrm{O}_{2}$ system. However, this work strongly supports the notion that $\mathrm{HO}^{\bullet}$, although potentially not the sole oxidative intermediate present, is certainly the dominant species formed.

\section{Marine Implications}

In this study we have tested simple model ligands as a proxy for the far more complex natural materials that bind $\mathrm{Fe}(\mathrm{II})$ in marine, estuarine and freshwater systems. This simplification is necessary due to the importance of thorough treatment of all potential radical reactions before any quantitative assessment of the yield of $\mathrm{HO}^{\bullet}$ production can be made. Even a ligand as simple as citrate introduces significant challenges in the interpretation of the data, with further work to constrain both the nature of the complexes formed as well as their individual ROS reactivity needed before a definitive conclusion could be drawn.

Although this study has further confirmed that at $\mathrm{pH} \sim 8$, inorganic $\mathrm{Fe}$ (II) does not react with $\mathrm{H}_{2} \mathrm{O}_{2}$ to give $\mathrm{HO}^{\bullet}$, it is still not clear why the nature of the oxidant formed on oxidation of inorganic $\mathrm{Fe}$ (II) by $\mathrm{H}_{2} \mathrm{O}_{2}$ is $\mathrm{pH}$ dependent, nor why the organic ligands that we have examined here are able to overcome this limitation. While it has been demonstrated that this same logic seems to apply to terrigeneous NOM (Miller et al., 2013), which would appear to be a good model of estuarine $\mathrm{Fe}(\mathrm{II})$ ligands (Hopwood et al., 2015), it is not clear if this is of relevance to oceanic Fe-ligands, which are known to be important controls on $\mathrm{Fe}(\mathrm{II})$ oxidation rates in the open ocean (Roy and Wells, 2011). It is also unknown how colloidal $\mathrm{Fe}(\mathrm{II})$ associated with organic material may behave (von der Heyden et al., 2014). It is also still unclear indeed what properties a complexing agent must have to promote formation of $\mathrm{HO}^{\bullet}$, however it would seem quite likely that complexed $\mathrm{Fe}(\mathrm{II})$ in marine, estuarine and freshwater environments would react with $\mathrm{H}_{2} \mathrm{O}_{2}$ to yield $\mathrm{HO}^{\bullet}$.

Despite the minimal role of cycling of Fe between the +2 and +3 oxidation states under the conditions of this work, in natural systems this process is potentially more important. As superoxide is now recognized to be produced in a wide variety of natural contexts (Shaked and Rose, 2013), a steady flux of superoxide may be sufficient to continually reduce $\mathrm{Fe}(\mathrm{III})$ complexes to the $\mathrm{Fe}(\mathrm{II})$ form, which combined with observed $\mathrm{H}_{2} \mathrm{O}_{2}$ concentrations on the order of tens to hundreds of nanomolar (Kieber and Helz,

\section{REFERENCES}

Amico, P., Daniele, P. G., Cucinotta, V., Rizzarelli, E., and Sammartano, S. (1979). Equilibrium study of iron(II) and manganese(II) complexes with citrate ion in aqueous solution: relevance to coordination of citrate to the active site of aconitase and to gastrointestinal absorption of some essential metal ions. Inorganica Chim. Acta 36, 1-7. doi: 10.1016/S0020-1693(00)89363-9

Avery, J. G. B., Cooper, W. J., Kieber, R. J., and Willey, J. D. (2005). Hydrogen peroxide at the Bermuda Atlantic Time Series Station: temporal
1995; Avery et al., 2005) may lead to a continual, albeit slow, production pathway for $\mathrm{HO}^{\bullet}$.

\section{CONCLUSIONS}

Under circumneutral conditions and in the presence of organic ligands, $\mathrm{Fe}(\mathrm{II})$ is oxidized by $\mathrm{H}_{2} \mathrm{O}_{2}$ to yield hydroxyl radicals. Competition experiments with $t$ - $\mathrm{BuOH}$ confirmed that $\mathrm{HO}^{\bullet}$ was indeed the species being measured. Kinetic modeling indicates that the difference in magnitude of $\mathrm{HO}^{\bullet}$ production between ligands can be adequately explained by consideration of all relevant reactions between $\mathrm{ROS}$ and $\mathrm{Fe}(\mathrm{II}) \mathrm{L} / \mathrm{Fe}(\mathrm{III}) \mathrm{L}$ without the need to invoke different $\mathrm{HO}^{\bullet}$-production efficiencies for various $\mathrm{Fe}(\mathrm{II}) \mathrm{L}$ complexes. Of particular importance are the reactions of $\mathrm{Fe}(\mathrm{II}) \mathrm{L}$ with $\mathrm{O}_{2}, \mathrm{O}_{2}^{\bullet-}$, and $\mathrm{H}_{2} \mathrm{O}_{2}$ and the reaction of $\mathrm{Fe}(\mathrm{III}) \mathrm{L}$ with $\mathrm{O}_{2}^{\bullet-}$. For the well-studied ligands EDTA and DTPA there is excellent agreement between model predictions and experimental results, with the poor $\mathrm{HO}^{\bullet}$ production predictions for $\mathrm{Fe}(\mathrm{II})$ citrate likely due to an incomplete description of the speciation and oxidation mechanism rather than the production of an alternative oxidant by $\mathrm{Fe}(\mathrm{II})$-citrate complexes. In the absence of organic ligands, no $\mathrm{HO}^{\bullet}$ production could be measured under conditions where $\mathrm{H}_{2} \mathrm{O}_{2}$ was the dominant oxidant of $\mathrm{Fe}$ (II). As such, it is concluded that, under the conditions of this work, inorganic $\mathrm{Fe}(\mathrm{II})$ and $\mathrm{H}_{2} \mathrm{O}_{2}$ react to form an intermediate that is not $\mathrm{HO}^{\bullet}$, the nature of which was unable to be examined. Overall, it is clear that under environmentally relevant conditions the Fenton reaction will only result in $\mathrm{HO}^{\bullet}$ production if $\mathrm{Fe}(\mathrm{II})$ is complexed by an organic ligand.

\section{AUTHOR CONTRIBUTIONS}

TW initiated the study which was undertaken by $\mathrm{CM}$ and supervised by TW and AR. All authors contributed to manuscript preparation.

\section{ACKNOWLEDGMENTS}

Funding provided through the Australian Research Council's Discovery Scheme (Project No. DP0987188) is gratefully acknowledged.

\section{SUPPLEMENTARY MATERIAL}

The Supplementary Material for this article can be found online at: http://journal.frontiersin.org/article/10.3389/fmars. 2016.00134

variability of seawater hydrogen peroxide. Mar. Chem. 97, 236-244. doi: 10.1016/j.marchem.2005.03.006

Backa, S., Gierer, J., Reitberger, T., and Nilsson, T. (1993). Hydroxyl radical activity associated with the growth of white-rot fungi. Holzforschung 47, 181-187. doi: 10.1515/hfsg.1993.47.3.181

Bataineh, H., Pestovsky, O., and Bakac, A. (2012). pH-induced mechanistic changeover from hydroxyl radicals to iron(IV) in the Fenton reaction. Chem. Sci. 3, 1594-1599. doi: 10.1039/c2sc $20099 f$ 
Bielski, B. H. J., Cabelli, D. E., Arudi, R. L., and Ross, A. B. (1985). Reactivity of $\mathrm{HO}_{2} / \mathrm{O}_{2}^{-}$radicals in aqueous solution. J. Phys. Chem. Ref. Data 14, 1041-1100. doi: $10.1063 / 1.555739$

Bolann, B. J., Henriksen, H., and Ulvik, R. J. (1992). Decay kinetics of $\mathrm{O}_{2}^{\bullet-}$ studied by direct spectrophotometry. Interaction with catalytic and non-catalytic substances. Biochim. Biophys. Acta Gen. Subj. 1156, 27-33. doi: 10.1016/03044165(92)90091-8

Bray, W. C., and Gorin, M. H. (1932). Ferryl ion, a compound of tetravalent iron. J. Am. Chem. Soc. 54, 2124-2125. doi: 10.1021/ja01344a505

Buettner, G. R., Doherty, T. P., and Patterson, L. K. (1983). The kinetics of the reaction of superoxide radical with Fe(III) complexes of EDTA, DETAPAC and HEDTA. FEBS Lett. 158, 143-146. doi: 10.1016/0014-5793(83)80695-4

Bull, C., Fee, J. A., O'neill, P., and Fielden, E. M. (1982). Ironethylenediaminetetraacetic acid (EDTA)-catalyzed superoxide dismutation revisited: an explanation of why the dismutase activity of Fe-EDTA cannot be detected in the cytochrome c/xanthine oxidase assay system. Arch. Biochem. Biophys. 215, 551-555. doi: 10.1016/0003-9861(82)90115-1

Bull, C., McClune, G. J., and Fee, J. A. (1983). The mechanism of iron EDTA catalyzed superoxide dismutation. J. Am. Chem. Soc. 105, 5290-5300. doi: 10.1021/ja00354a019

Butler, J., and Halliwell, B. (1982). Reaction of iron-EDTA chelates with the superoxide radical. Arch. Biochem. Biophys. 218, 174-178. doi: 10.1016/00039861(82)90333-2

Buxton, G. V., Greenstock, C. L., Helman, W. P., and Ross, A. B. (1988). Critical review of rate constants for reactions of hydrated electrons, hydrogen atoms and hydroxyl radicals $\left({ }^{\bullet} \mathrm{OH} /{ }^{\bullet} \mathrm{O}^{-}\right)$in aqueous solution. J. Phys. Chem. Ref. Data 17, 513-886. doi: 10.1063/1.555805

Buxton, G. V., Sellers, R. M., and McCracken, D. R. (1976). Pulse radiolysis study of monovalent cadmium, cobalt, nickel and zinc in aqueous solution. Part 2.Reactions of the monovalent ions. J. Chem. Soc. Faraday Trans. 1: Phys. Chem. Condens. Phases 72, 1464-1476. doi: 10.1039/f19767201464

Cabelli, D. E., Rush, J. D., Thomas, M. J., and Bielski, B. H. J. (1989). Kinetics of the free-radical-induced reduction of (diethylenetriaminepentaacetato)iron(III) to (diethylenetriaminepentaacetato)iron(II): a pulse radiolysis study. J. Phys. Chem. 93, 3579-3586. doi: 10.1021/j100346a042

Croft, S., Gilbert, B. C., Smith, J. R. L., and Whitwood, A. C. (1992). An E.S.R. investigation of the reactive intermediate generated in the reaction between $\mathrm{Fe}^{\mathrm{II}}$ and $\mathrm{H}_{2} \mathrm{O}_{2}$ in aqueous solution. Direct evidence for the formation of the hydroxyl radical. Free Radic. Res. 17, 21-39. doi: 10.3109/10715769209061086

Dorfman, L. M., Taub, I. A., and Buhler, R. E. (1962). Pulse radiolysis studies. I. Transient spectra and reaction-rate constants in irradiated aqueous solutions of benzene. J. Chem. Phys. 36, 3051-3061. doi: 10.1063/1.1732425

Duesterberg, C. K., Cooper, W. J., and Waite, T. D. (2005). Fenton-mediated oxidation in the presence and absence of oxygen. Environ. Sci. Technol. 39, 5052-5058. doi: 10.1021/es048378a

Dunford, H. B. (2002). Oxidations of iron(II)/(III) by hydrogen peroxide: from aquo to enzyme. Coord. Chem. Rev. 233-234, 311-318. doi: 10.1016/S00108545(02)00024-3

Fujii, M., Dang, T. C., Rose, A. L., Omura, T., and Waite, T. D. (2011). Effect of light on iron uptake by the freshwater cyanobacterium Microcystis aeruginosa. Environ. Sci. Technol. 45, 1391-1398. doi: 10.1021/es103311h

Fujii, M., Rose, A. L., Waite, T. D., and Omura, T. (2008). Effect of divalent cations on the kinetics of $\mathrm{Fe}$ (III) complexation by organic ligands in natural waters. Geochim. Cosmochim. Acta 72, 1335-1349. doi: 10.1016/j.gca.2007.12.017

Garg, S., Rose, A. L., and Waite, T. D. (2007). Superoxide mediated reduction of organically complexed iron(III): comparison of non-dissociative and dissociative reduction pathways. Environ. Sci. Technol. 41, 3205-3212. doi: 10.1021/es0617892

Goldstein, S., and Meyerstein, D. (1999). Comments on the mechanism of the "Fenton-like" reaction. Acc. Chem. Res. 32, 547-550. doi: 10.1021/ar9800789

Goldstein, S., Meyerstein, D., and Czapski, G. (1993). The Fenton reagents. Free Radic. Biol. Med. 15, 435-445. doi: 10.1016/0891-5849(93) 90043-T

González-Dávila, M., Santana-Casiano, J. M., and Millero, F. J. (2005). Oxidation of iron(II) nanomolar with $\mathrm{H}_{2} \mathrm{O}_{2}$ in seawater. Geochim. Cosmochim. Acta 69, 83-93. doi: 10.1016/j.gca.2004.05.043

Graf, E., Mahoney, J. R., Bryant, R. G., and Eaton, J. W. (1984). Iron-catalyzed hydroxyl radical formation. Stringent requirement for free iron coordination site. J. Biol. Chem. 259, 3620-3624.
Gutteridge, J. M. C. (1991). Hydroxyl radical formation from the auto-reduction of a ferric citrate complex. Free Radic. Biol. Med. 11, 401-406. doi: 10.1016/08915849(91)90157-X

Hill-Cottingham, D. G. (1955). Spectrophotometric determination of iron chelates. Analyst 80, 906-908.

Höbel, B., and von Sonntag, C. (1998). OH-Radical induced degradation of ethylenediaminetetraacetic acid (EDTA) in aqueous solution: a pulse radiolysis study. J. Chem. Soc. Perkin Trans. 2, 509-514. doi: 10.1039/a708167g

Hopwood, M. J., Statham, P. J., Skrabal, S. A., and Willey, J. D. (2015). Dissolved iron(II) ligands in river and estuarine water. Mar. Chem. 173, 173-182. doi: 10.1016/j.marchem.2014.11.004

Hug, S. J., and Leupin, O. (2003). Iron-catalyzed oxidation of arsenic(III) by oxygen and by hydrogen peroxide: $\mathrm{pH}$-Dependent formation of oxidants in the Fenton reaction. Environ. Sci. Technol. 37, 2734-2742. doi: 10.1021/es026208x

Ianni, J. C. (2003). "A comparison of the Bader-Deuflhard and the Cash-Karp Runge-Kutta integrators for the GRI-MECH 3.0 model based on the chemical kinetics code Kintecus," in Computational Fluid and Solid Mechanics, ed K. J. Bathe (Oxford: Elsevier Science Ltd.), 1368-1372.

Ilan, Y. A., and Czapski, G. (1977). The reaction of superoxide radical with iron complexes of EDTA studied by pulse radiolysis. Biochim. Biophys. Acta Gen. Subj. 498, 386-394. doi: 10.1016/0304-4165(77)90277-X

Jomova, K., Baros, S., and Valko, M. (2012). Redox active metal-induced oxidative stress in biological systems. Transit. Metal Chem. 37, 127-134. doi: 10.1007/s11243-012-9583-6

Keenan, C. R., and Sedlak, D. L. (2008). Factors affecting the yield of oxidants from the reaction of nanoparticulate zero-valent iron and oxygen. Environ. Sci. Technol. 42, 1262-1267. doi: 10.1021/es7025664

Kieber, R. J., and Helz, G. R. (1995). Temporal and seasonal variations of hydrogen peroxide levels in estuarine waters. Estuar. Coast. Shelf Sci. 40, 495-503. doi: 10.1006/ecss.1995.0034

King, D. W., and Farlow, R. (2000). Role of carbonate speciation on the oxidation of $\mathrm{Fe}(\mathrm{II})$ by $\mathrm{H}_{2} \mathrm{O}_{2}$. Mar. Chem. 70, 201-209. doi: 10.1016/S03044203(00)00026-8

Königsberger, L. C., Königsberger, E., May, P. M., and Hefter, G. T. (2000). Complexation of iron(III) and iron(II) by citrate. Implications for iron speciation in blood plasma. J. Inorg. Biochem. 78, 175-184. doi: 10.1016/S01620134(99)00222-6

Kosaka, H., Katsuki, Y., and Shiga, T. (1992). Spin trapping study on the kinetics of $\mathrm{Fe}^{2+}$ autoxidation: formation of spin adducts and their destruction by superoxide. Arch. Biochem. Biophys. 293, 401-408. doi: 10.1016/00039861(92)90412-P

Kremer, M. L. (1999). Mechanism of the Fenton reaction. Evidence for a new intermediate. Phys. Chem. Chem. Phys. 1, 3595-3605. doi: 10.1039/a903915e

Kundu, K. P., and Matsuura, N. (1975). Gamma-radiolysis of ferric ethylene diamine tetra-acetate in neutral aqueous solution. Int. J. Radiat. Phys. Chem. 7, 565-571. doi: 10.1016/0020-7055(75)90021-2

Kwan, W. P., and Voelker, B. M. (2002). Decomposition of hydrogen peroxide and organic compounds in the presence of dissolved iron and ferrihydrite. Environ. Sci. Technol. 36, 1467-1476. doi: 10.1021/es011109p

Lati, J., and Meyerstein, D. (1978). Oxidation of first-row bivalent transitionmetal complexes containing ethylenediaminetetra-acetate and nitrilotriacetate ligands by free radicals: a pulse-radiolysis study. J. Chem. Soc. Dalton Trans. 1978, 1105-1118. doi: 10.1039/dt9780001105

Lee, H., Lee, H.-J., Sedlak, D. L., and Lee, C. (2013). pH-Dependent reactivity of oxidants formed by iron and copper-catalyzed decomposition of hydrogen peroxide. Chemosphere 92, 652-658. doi: 10.1016/j.chemosphere.2013.01.073

Lee, J.-C., Son, Y.-O., Pratheeshkumar, P., and Shi, X. (2012). Oxidative stress and metal carcinogenesis. Free Radic. Biol. Med. 53, 742-757. doi: 10.1016/j.freeradbiomed.2012.06.002

Luzzatto, E., Cohen, H., Stockheim, C., Wieghardt, K., and Meyerstein, D. (1995). Reactions of low valent transition metal complexes with hydrogen peroxide. Are they "Fenton-like" or not? 4. The case of Fe(II)L, L = EDTA; HEDTA and TCMA. Free Radic. Res. 23, 453-463. doi: 10.3109/10715769509065266

MacFaul, P. A., Wayner, D. D. M., and Ingold, K. U. (1998). A radical account of "Oxygenated Fenton Chemistry." Acc. Chem. Res. 31, 159-162. doi: 10.1021/ar970057z

Masarwa, A., Rachmilovich-Calis, S., Meyerstein, N., and Meyerstein, D. (2005). Oxidation of organic substrates in aerated aqueous solutions by the Fenton reagent. Coord. Chem. Rev. 249, 1937-1943. doi: 10.1016/j.ccr.2005.01.003 
Miller, C. J., Lee, S. M. V., Rose, A. L., and Waite, T. D. (2012). Impact of natural organic matter on $\mathrm{H}_{2} \mathrm{O}_{2}$-mediated oxidation of $\mathrm{Fe}$ (II) in coastal seawaters. Environ. Sci. Technol. 46, 11078-11085. doi: 10.1021/es3022792

Miller, C. J., Rose, A. L., and Waite, T. D. (2009). Impact of natural organic matter on $\mathrm{H}_{2} \mathrm{O}_{2}$-mediated oxidation of $\mathrm{Fe}$ (II) in a simulated freshwater system. Geochim. Cosmochim. Acta 73, 2758-2768. doi: 10.1016/j.gca.2009.02.027

Miller, C. J., Rose, A. L., and Waite, T. D. (2011). Phthalhydrazide chemiluminescence method for determination of hydroxyl radical production: modifications and adaptations for use in natural systems. Anal. Chem. 83, 261-268. doi: 10.1021/ac1022748

Miller, C. J., Rose, A. L., and Waite, T. D. (2013). Hydroxyl radical production by $\mathrm{H}_{2} \mathrm{O}_{2}$-mediated oxidation of $\mathrm{Fe}$ (II) complexed by Suwannee River fulvic acid under circumneutral freshwater conditions. Environ. Sci. Technol. 47, 829-835. doi: 10.1021/es303876h

Morgan, M. S., Van Trieste, P. F., Garlick, S. M., Mahon, M. J., and Smith, A. L. (1988). Ultraviolet molar absorptivities of aqueous hydrogen peroxide and hydroperoxyl ion. Anal. Chim. Acta 215, 325-329. doi: 10.1016/S00032670(00)85294-0

Neta, P., Grodkowski, J., and Ross, A. B. (1996). Rate constants for reactions of aliphatic carbon-centred radicals in aqueous solutions. J. Phys. Chem. Ref. Data 25, 709-1050. doi: 10.1063/1.555978

Pham, A. N., and Waite, T. D. (2008). Oxygenation of Fe(II) in natural waters revisited: kinetic modeling approaches, rate constant estimation and the importance of various reaction pathways. Geochim. Cosmochim. Acta 72, 3616-3630. doi: 10.1016/j.gca.2008.05.032

Rachmilovich-Calis, S., Masarwa, A., Meyerstein, N., Meyerstein, D., and Van Eldik, R. (2009a). New mechanistic aspects of the Fenton reaction. Chem. A Eur. J. 15, 8303-8309. doi: 10.1002/chem.200802572

Rachmilovich-Calis, S., Meyerstein, N., and Meyerstein, D. (2009b). A mechanistic study of the effects of antioxidants on the formation of malondialdehyde-like products in the reaction of hydroxyl radicals with deoxyribose. Chem. A Eur. J. 15, 7717-7723. doi: 10.1002/chem.200802272

Rahhal, S., and Richter, H. W. (1988). Reduction of hydrogen peroxide by the ferrous iron chelate of diethylenetriamine-N,N,N,N",N"-pentaacetate. J. Am. Chem. Soc. 110, 3126-3133. doi: 10.1021/ja00218a022

Rahhal, S., and Richter, H. W. (1989). Reaction of hydroxyl radicals with the ferrous and ferric iron chelates of diethylenetriamine-N,N,N'N",N"pentaacetate. Free Radic. Res. 6, 369-377. doi: 10.3109/10715768909087920

Remucal Keenan, C., and Sedlak, D. L. (2011). "The role of iron coordination in the production of reactive oxidants from ferrous iron oxidation by oxygen and hydrogen peroxide," in Aquatic Redox Chemistry, eds P. G. Tratnyek, T. J. Grundl, and S. B. Haderlein (Washington, DC: American Chemical Society), 177-197.

Rose, A. L., and Waite, T. D. (2001). Chemiluminescence of luminol in the presence of iron(II) and oxygen: oxidation mechanism and implications for its analytical use. Anal. Chem. 73, 5909-5920. doi: 10.1021/ac015547q

Rose, A. L., and Waite, T. D. (2005). Reduction of organically complexed ferric iron by superoxide in a simulated natural water. Environ. Sci. Technol. 39, 2645-2650. doi: 10.1021/es048765k

Roy, E. G., and Wells, M. L. (2011). Evidence for regulation of Fe(II) oxidation by organic complexing ligands in the Eastern Subarctic Pacific. Mar. Chem. 127, 115-122. doi: 10.1016/j.marchem.2011.08.006

Rush, J. D., and Koppenol, W. H. (1986). Oxidizing intermediates in the reaction of ferrous EDTA with hydrogen peroxide. Reactions with organic molecules and ferrocytochrome c. J. Biol. Chem. 261, 6730-6733.

Rush, J. D., and Koppenol, W. H. (1987). The reaction between ferrous polyaminocarboxylate complexes and hydrogen peroxide: an investigation of the reaction intermediates by stopped flow spectrophotometry. J. Inorg. Biochem. 29, 199-215. doi: 10.1016/0162-0134(87)80027-2

Santana-Casiano, J. M., González-Dávila, M., and Millero, F. J. (2005). Oxidation of nanomolar levels of $\mathrm{Fe}$ (II) with oxygen in natural waters. Environ. Sci. Technol. 39, 2073-2079. doi: 10.1021/es049748y

Santana-Casiano, J. M., González-Dávila, M., and Millero, F., J. (2006). The role of $\mathrm{Fe}(\mathrm{II})$ species on the oxidation of $\mathrm{Fe}(\mathrm{II})$ in natural waters in the presence of $\mathrm{O}_{2}$ and $\mathrm{H}_{2} \mathrm{O}_{2}$. Mar. Chem. 99, 70-82. doi: 10.1016/j.marchem.2005.03.010

Schiller, J., Arnhold, J., Schwinn, J., Sprinz, H., Brede, O., and Arnold, K. (1999). Differences in the reactivity of phthalic hydrazide and luminol with hydroxyl radicals. Free Radic. Res. 30, 45-57. doi: 10.1080/10715769900300061
Seibig, S., and Van Eldik, R. (1997). Kinetics of [Fe ${ }^{\mathrm{II}}$ (edta)] oxidation by molecular oxygen revisited. New evidence for a multistep mechanism. Inorg. Chem. 36, 4115-4120. doi: 10.1021/ic970158t

Shaked, Y., and Rose, A. L. (2013). Seas of superoxide. Science 340, 1176-1177. doi: $10.1126 /$ science. 1240195

Summers, J. S., Baker, J. B., Meyerstein, D., Mizrahi, A., Zilbermann, I., Cohen, H., et al. (2008). Measured rates of fluoride/metal association correlate with rates of superoxide/metal reactions for $\mathrm{Fe}^{\mathrm{III}} \mathrm{EDTA}\left(\mathrm{H}_{2} \mathrm{O}\right)^{-}$and related complexes. $J$. Am. Chem. Soc. 130, 1727-1734. doi: 10.1021/ja077193b

Sutton, H. C. (1985). Efficiency of chelated iron compounds as catalysts for the Haber-Weiss reaction. J. Free Radic. Biol. Med. 1, 195-202. doi: 10.1016/07485514(85)90118-7

Vile, G. F., Winterbourn, C. C., and Sutton, H. C. (1987). Radical-driven fenton reactions: studies with paraquat, adriamycin, and anthraquinone 6-sulfonate and citrate, ATP, ADP, and pyrophosphate iron chelates. Arch. Biochem. Biophys. 259, 616-626. doi: 10.1016/0003-9861(87)90528-5

von der Heyden, B. P., Hauser, E. J., Mishra, B., Martinez, G. A., Bowie, A. R., Tyliszczak, T., et al. (2014). Ubiquitous presence of Fe(II) in aquatic colloids and its association with organic carbon. Environ. Sci. Technol. Lett. 1, 387-392. doi: 10.1021/ez500164v

von Sonntag, C. (2008). Advanced oxidation processes: mechanistic aspects. Water Sci. Technol. 58, 1015-1021. doi: 10.2166/wst.2008.467

von Sonntag, C., Dowideit, P., Xingwang, F., Mertens, R., Xianming, P., Schuchmann, M. N., et al. (1997). The fate of peroxyl radicals in aqueous solution. Water Sci. Technol. 35, 9-15. doi: 10.1016/S0273-1223(97)00003-6

Walling, C. (1998). Intermediates in the reactions of Fenton type reagents. Acc. Chem. Res. 31, 155-157. doi: 10.1021/ar9700567

White, E. M., Vaughan, P. P., and Zepp, R. G. (2003). Role of the photo-Fenton reaction in the production of hydroxyl radicals and photobleaching of colored dissolved organic matter in a coastal river of the southeastern United States. Aquat. Sci. 65, 402-414. doi: 10.1007/s00027-003-0675-4

Winterbourn, C. C. (1995). Toxicity of iron and hydrogen peroxide: the Fenton reaction. Toxicol. Lett. 82-83, 969-974. doi: 10.1016/0378-4274(95)03532-X

Wulkow, M. (2004). Presto-Simulation of Kinetic Models. Rastede: CiT GmbH.

Yamazaki, I., and Piette, L. H. (1990). ESR spin-trapping studies on the reaction of $\mathrm{Fe}^{2+}$ ions with $\mathrm{H}_{2} \mathrm{O}_{2}$-reactive species in oxygen toxicity in biology. J. Biol. Chem. 265, 13589-13594.

Yamazaki, I., and Piette, L. H. (1991). ESR spin-trapping study on the oxidizing species formed in the reaction of the ferrous ion with hydrogen peroxide. $J$. Am. Chem. Soc. 113, 7588-7593. doi: 10.1021/ja00020a021

Yu, X.-Y. (2004). Critical evaluation of rate constants and equilibrium constants of hydrogen peroxide photolysis in acidic aqueous solutions containing chloride ions. J. Phys. Chem. Ref. Data 33, 747-763. doi: 10.1063/1.1695414

Yurkova, I. L., Schuchmann, H.-P., and Von Sonntag, C. (1999). Production of OH radicals in the autoxidation of the Fe(II)-EDTA system. J. Chem. Soc. Perkin Trans. 2: Phys. Org. Chem. 10, 2049-2052. doi: 10.1039/a904739e

Zang, V., and Van Eldik, R. (1990a). Influence of the polyamino carboxylate chelating ligand (L) on the kinetics and mechanism of the formation of $\mathrm{Fe}^{\mathrm{II}}(\mathrm{L}) \mathrm{NO}$ in the system $\mathrm{Fe}^{\mathrm{II}}(\mathrm{L}) / \mathrm{NO} / \mathrm{HONO} / \mathrm{NO}_{2}^{-}$in aqueous solution. Inorg. Chem. 29, 4462-4468. doi: 10.1021/ic00347a026

Zang, V., and Van Eldik, R. (1990b). Kinetics and mechanism of the autoxidation of iron(II) induced through chelation by ethylenediaminetetraacetate and related ligands. Inorg. Chem. 29, 1705-1711. doi: 10.1021/ic00334a023

Zepp, R. G., Faust, B. C., and Hoigne, J. (1992). Hydroxyl radical formation in aqueous reactions ( $\mathrm{pH} 3-8$ ) of iron(II) with hydrogen peroxide: the photo-Fenton reaction. Environ. Sci. Technol. 26, 313-319. doi: 10.1021/es000 $26 \mathrm{a} 011$

Conflict of Interest Statement: The authors declare that the research was conducted in the absence of any commercial or financial relationships that could be construed as a potential conflict of interest.

Copyright (c) 2016 Miller, Rose and Waite. This is an open-access article distributed under the terms of the Creative Commons Attribution License (CC BY). The use, distribution or reproduction in other forums is permitted, provided the original author(s) or licensor are credited and that the original publication in this journal is cited, in accordance with accepted academic practice. No use, distribution or reproduction is permitted which does not comply with these terms. 